\title{
Changes in the growth, ileal digestibility, intestinal histology, behavior, fatty acid composition of the breast muscles, and blood biochemical parameters of broiler chickens by dietary inclusion of safflower oil and vitamin C
}

Shimaa A. Amer ${ }^{1 *}$ (D), Wafaa A. M. Mohamed ${ }^{2}$, Heba S. A. Gharib ${ }^{3}$, Naif A. Al-Gabri ${ }^{4}$, Ahmed Gouda ${ }^{5}$, Mohamed Tharwat Elabbasy ${ }^{6,7}$, Ghada I. Abd El-Rahman ${ }^{2}$ and Anaam E. Omar ${ }^{1}$

\begin{abstract}
Background: The effects of safflower oil and vitamin C (Vit. C) inclusion in broiler chicken diets on the growth performance, apparent ileal digestibility coefficient "AID\%" of amino acids, intestinal histology, behavior, carcass traits, fatty acid composition of the breast muscle, antioxidant and immune status for a 35-day feeding period were evaluated. A total of 300 three-day-old Ross chicks $(58.25 \mathrm{~g} \pm 0.19)$ were randomly allotted in a $2 \times 3$ factorial design consisting of two levels of vitamin C ( 0 and $400 \mathrm{mg} / \mathrm{kg}$ diet) and three levels of safflower oil $(0,5$, and $10 \mathrm{~g} / \mathrm{kg}$ diet).

Results: An increase in the final body weight, total body weight gain, total feed intake, and the relative growth rate $(P<0.05)$ were reported by safflower oil and vitamin $C$ inclusion. Dietary supplementation of safflower oil and vitamin $C$ had a positive effect $(P<0.05)$ on the ingestive, resting, and feather preening behavior. Vitamin $C$ supplementation increased $(P<0.05)$ the AID\% of lysine, threonine, tryptophan, arginine, and valine. Safflower inclusion $(10 \mathrm{~g} / \mathrm{kg})$ increased $(P<0.05)$ the AID\% of methionine and isoleucine. Safflower oil inclusion increased $(P<0.05)$ the levels of stearic acid, linoleic acid, saturated fatty acids, and omega-3 fatty acids $(\omega-3)$ in the breast muscle. In contrast, the supplementation of only $10 \mathrm{~g}$ of safflower oil/ $\mathrm{kg}$ diet increased $(P=0.01)$ the omega-3/ omega-6 $(\omega-3 / \omega-6)$ fatty acids ratio. Vit. $C$ supplementation increased $(P<0.05)$ the CAT serum levels, SOD, and GSH enzymes. Dietary supplementation of safflower oil and vitamin C improved the intestinal histology.

They increased the villous height and width, crypt depth, villous height/crypt depth ratio, mucosal thickness, goblet cell count, and intra-epithelium lymphocytic lick cell infiltrations. The serum levels of IgA and complement C3 were increased $(P<0.01)$ by Vit. $C$ supplementation and prominent in the 400 vit. $C+10$ safflower Oil group.

* Correspondence: shimaa.amer@zu.edu.eg

${ }^{1}$ Department of Nutrition \& Clinical Nutrition, Faculty of Veterinary Medicine, Zagazig University, Zagazig 44511, Egypt

Full list of author information is available at the end of the article

C The Author(s). 2021 Open Access This article is licensed under a Creative Commons Attribution 4.0 International License, which permits use, sharing, adaptation, distribution and reproduction in any medium or format, as long as you give appropriate credit to the original author(s) and the source, provide a link to the Creative Commons licence, and indicate if changes were made. The images or other third party material in this article are included in the article's Creative Commons licence, unless indicated otherwise in a credit line to the material. If material is not included in the article's Creative Commons licence and your intended use is not permitted by statutory regulation or exceeds the permitted use, you will need to obtain permission directly from the copyright holder. To view a copy of this licence, visit http://creativecommons.org/licenses/by/4.0/ The Creative Commons Public Domain Dedication waiver (http://creativecommons.org/publicdomain/zero/1.0/) applies to the data made available in this article, unless otherwise stated in a credit line to the data. 
(Continued from previous page)

Conclusion: A dietary combination of safflower oil and vitamin C resulted in improved growth rate, amino acids AID\%, intestinal histology, welfare, immune and antioxidant status of birds, and obtaining $\omega-3$ and linoleic acidenriched breast muscles. The best inclusion level was 400 vit. C + 10 safflower Oil.

Keywords: Broiler chicken, Safflower oil, Vitamin C, lleal digestibility, Fatty acid composition

\section{Background}

The fatty acids "FA" composition of broiler carcass can be modified by enriching it with high levels of essential polyunsaturated fatty acids (PUFA) through the dietary supplementation of plant seed oils [1-4]. Plant-rich oils contain high levels of polyunsaturated fatty acids (PUFA) but vary in the composition of essential FA. Consequently, these oils improve the PUFA carcass content with a different effect on the composition of overall fatty acid carcasses when fed to chicken $[3,5]$.

The reported benefits of polyunsaturated fatty acids on human health have increased the interest in foods containing these fatty acids in higher concentrations [3, 6-8]. The body's FA composition is mainly dependent on the contribution of hepatic lipid and external dietary fat as a source of FA deposits in the body. Dietary supplements affect each of these parameters and work either in an identical or reverse manner, depending on the diet composition. Fatty acids C18:2 and C18:3 are indispensable and cannot be synthesized; they are ingested through the dietary fat. The biochemical pathway of FA biosynthesis is affected by the dietary FA availability.

Safflower has been cultured locally for its oil, meal, and flower [9]. The normal-hull seeds contain 5-8\% moisture, $27-32 \%$ oil, $14-15 \%$ protein, $32-40 \%$ crude fiber, and $2-7 \%$ ash $[10,11]$. Safflower is one of the preeminent crops with variations in fatty acid composition in seed oil [12]. Common safflower oil encloses around $71-75 \%$ linoleic acid, 2-3\% stearic acid, 16-20\% oleic acid, and 6-8\% palmitic acid [13]. Safflower oil contains $79 \%$ of fatty acids as C18:2 (n-6), 11\% as C18:1 (n-9), and $0.5 \%$ as $\mathrm{C} 18: 3(\mathrm{n}-3)$ [14]. Conjugated linoleic acid (CLA) is a broad name for the positional and arithmetical isomers of linoleic acid ( 9 cis, 12 cis octadecadienoic acid; 18:2 (n-6)). In various mammalian species and chickens, it is observed that the fat deposition decreases by dietary conjugated linoleic acid $[15,16]$ that enhances skeletal muscle fatty acid $\beta$-oxidation $[17,18]$. This effect is demonstrated by the up-regulation of the carnitine palmitoyltransferase I (CPT-I, the main enzyme for $\beta$ oxidation) in skeletal muscles [19-21].

The main reason for meat and meat product deterioration is fat oxidation. High levels of PUFA in the poultry meat make it more liable to fatty acid oxidation; this oxidation can be increased by particular feeding strategies [22]. Although dietary handling results in increasing muscle tissue level, unsaturation increases the poultry meat vulnerability to oxidative degradation [23]. This leads to the formation of many products, including short-chain aldehydes, ketones, and other oxygenated compounds that can badly influence the overall meat quality and decrease its nutritional value [24]. Therefore, food supplements are an easy and suitable approach to include antioxidant compounds in chicken meat.

Vitamin $\mathrm{C}$ acts as an antioxidant because it protects the cellular components from free radical damage. Like most monogastric animals, Poultry synthesizes sufficient ascorbic acid for normal development and growth [25, 26]. Attia, et al. [27] demonstrated a positive effect of vitamin $\mathrm{C}$ supplementation, both in isolation and in combination with vitamin $\mathrm{E}$ and probiotics, in alleviating the adverse effects of chronic heat stress on the growth and immunity of broiler chickens. Moreover, Vitamin C supplementation is reported to effectively reduce the serum cholesterol concentration and the expression of heat shock protein 70 (HSP70) gene in the heart and liver of heat-stressed broilers [28]. Ascorbic acid reduces the formation of tocopherol radicals during free radical scavenging in the metabolism. The rejuvenated vitamin E molecule works as an antioxidant again or it is stored [29]. Thus, dietary vitamin $C$ improves the antioxidant status of chicken tissues [30, 31]. Vitamin C plays a significant role in interacting with all types of aggressive oxygen molecules under essentially inactive radical formation and transferring the radical equivalent from the fatty stages to the water molecules [32, 33].

To our knowledge, no information is available on the effect of including a combination of safflower oil and vitamin $\mathrm{C}$ in broiler chicken diets. Therefore, this study aims to assess the impact of safflower oil and vitamin $C$ inclusion in broiler chicken diets on the growth performance, amino acid ileal digestibility, carcass traits, behavior, breast muscle FA composition, intestinal histology, and immunological and antioxidant status of broiler chickens.

\section{Results}

\section{Growth performance}

Table 1 shows the effect of dietary inclusion of safflower oil and vitamin $\mathrm{C}$ on broiler chickens' growth performance. In the starter stage, dietary inclusion of $400 \mathrm{mg}$ vitamin $\mathrm{C} / \mathrm{kg}$ diet (Vit.C400) resulted in a significantly 


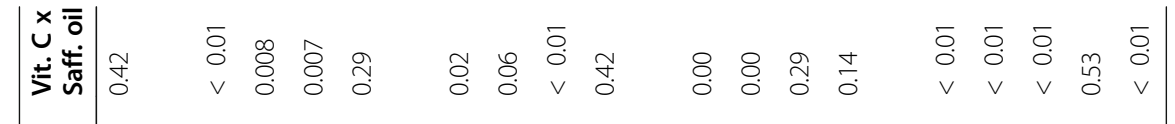

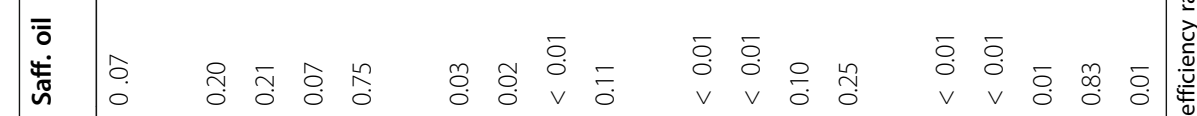

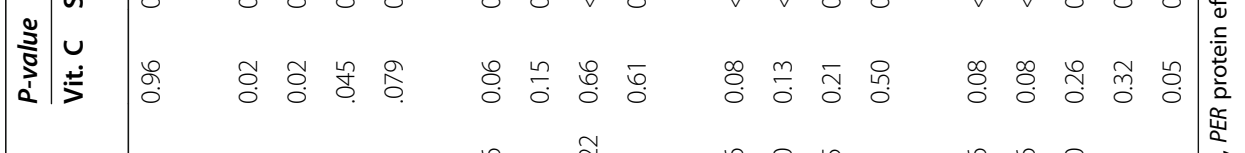

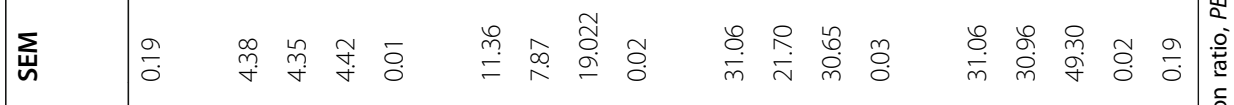

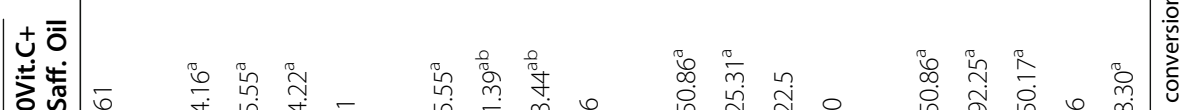
চơ

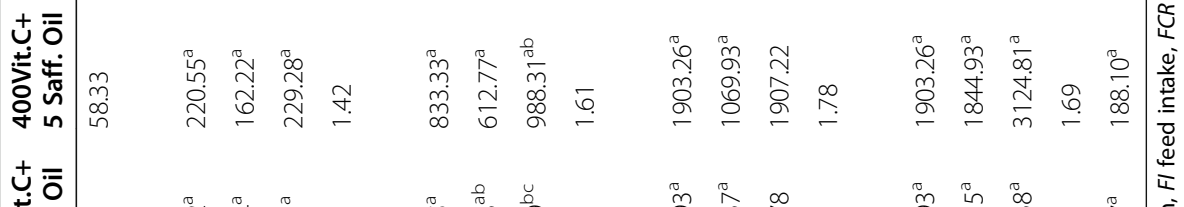

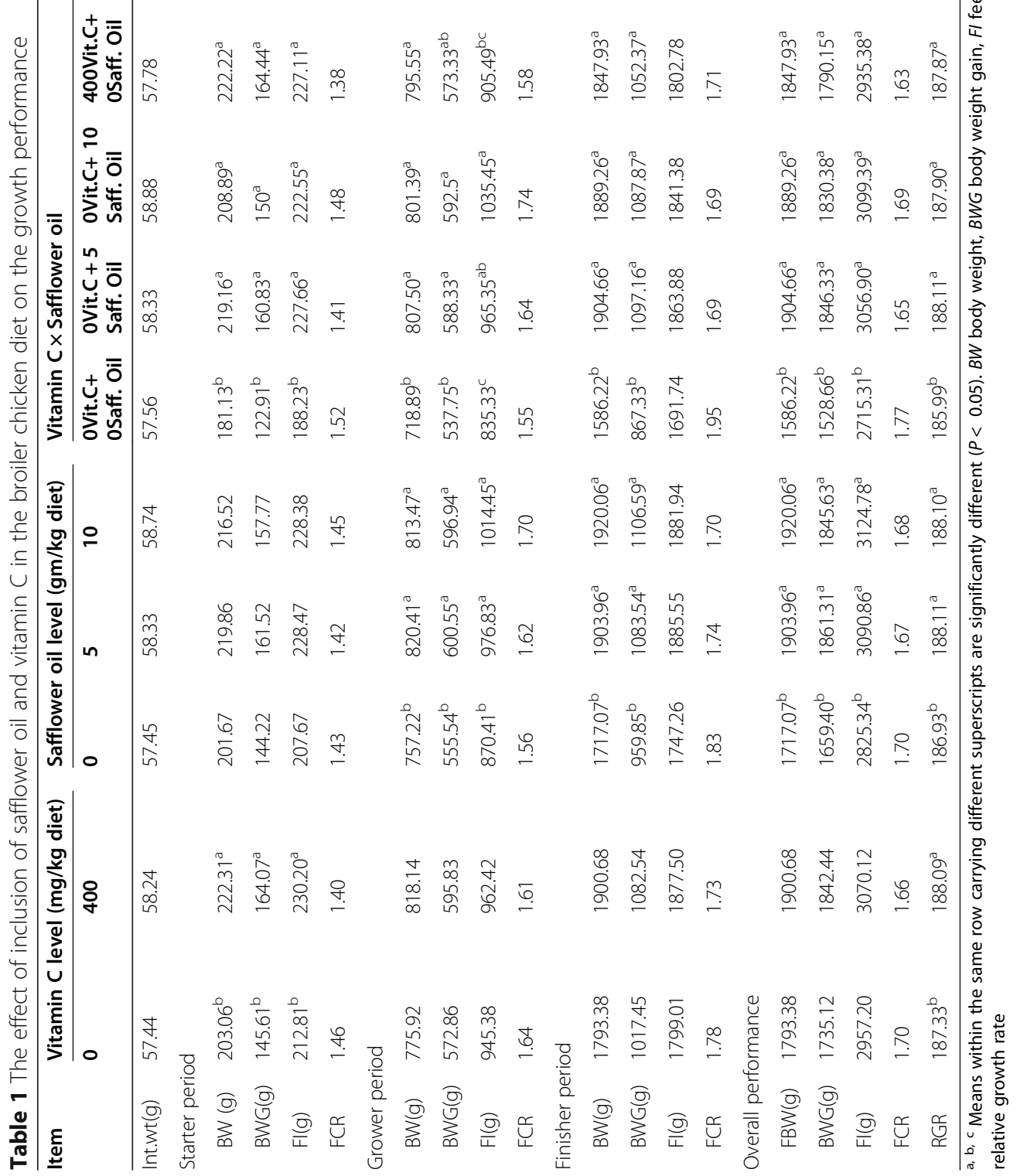


higher BW $(P=0.02)$, BWG $(P=0.02)$, and FI $(P=0.04)$. The safflower oil level had no significant effect on the BW, BWG, FI, and FCR $(P>0.05)$. The interaction between vitamin $C$ and safflower oil resulted in a significant increase in the BW, BWG, and FI $(P<0.05)$ in the groups fed diets supplemented with vitamin $C$ and safflower oil.

In the grower stage, the BW, BWG, and FI increased significantly by safflower oil inclusion $(P<0.05)$. The dietary inclusion of vitamin $C$ had no significant effect on the BW, BWG, FI, and FCR $(P>0.05)$. The bird weights increased significantly $(P=0.02)$ by feeding them a diet containing vitamin $\mathrm{C}$ and safflower oil. The BWG and FI of birds fed on a diet containing safflower oil alone or a combination of safflower oil and vitamin $\mathrm{C}$ were significantly higher $(P<0.05)$.

In the finisher stage, dietary safflower oil inclusion resulted in a significant increase in the birds' BW and BWG $(P<0.01)$. The dietary inclusion of vitamin $C$ produced no significant effect on the BW, BWG, FI, and FCR $(P>0.05)$. Interaction between vitamin $C$ and safflower oil resulted in a significant increase in the BW and BWG $(P<0.05)$ in the groups of birds fed diets supplemented with vitamin $C$ and safflower oil. The final BW, total BWG, and total FI increased significantly $(P<0.05)$ upon the inclusion of safflower oil and vitamin $C$. The relative growth rate "RGR" increased significantly $(P<0.01)$ by the dietary inclusion of safflower oil and vitamin $C$. No significant difference was observed in the FCR by the inclusion of safflower oil and vitamin $C$ throughout the experimental periods $(P>0.05)$.

\section{Apparent ileal digestibility coefficient "AID\%" of amino acids}

Table 2 highlights the effect of including safflower oil and vitamin $\mathrm{C}$ in broiler chicken diets on the AID\% of various amino acids. Dietary supplementation with a
$400 \mathrm{mg} / \mathrm{kg}$ diet of vitamin C significantly increased $(P<0.05)$ the AID\% of lysine, threonine, tryptophan, arginine, and valine compared to the zero inclusion level (a diet without any supplementation). However, it did not have any significant effect $(P>0.05)$ on the AID\% of methionine, leucine, and isoleucine. Dietary inclusion of a $10 \mathrm{~g} / \mathrm{kg}$ diet of safflower significantly increased the AID\% of methionine and isoleucine $(P<0.05)$ and decreased the AID\% of leucine $(P<0.01)$ compared to zero inclusion level. The interaction between vitamin $C$ and safflower oil resulted in a significant increase in (a) the lysine AID\% $(P<0.01)$ in the 0Vit.C +5 Saff. Oil, 400Vit.C + 0 Saff. Oil, 400Vit.C + 5 Saff. Oil, and 400Vit. +10 Saff. Oil groups; (b) the methionine AID\% $(P<0.01)$ in the 0Vit.C +5 Saff. Oil, 0Vit.C +10 Saff. Oil, 400Vit.C +0 Saff. Oil, and 400Vit.C +10 Saff. Oil groups; (c) the threonine AID\% $(P<0.01)$ in the 0Vit.C + 5 Saff. Oil, 0Vit.C+10 Saff. Oil, 400Vit.C + 0 Saff. Oil, and the 400Vit.C + 10 Saff. Oil groups; (d) the tryptophan AID\% $(P<0.01)$ in the 400Vit.C +10 Saff. Oil group; (e) the arginine AID\% $(P<0.01)$ in the 400Vit.C + 0 Saff. Oil group; (f) the leucine AID\% $(P<0.01)$ in the 400Vit.C +0 Saff. Oil group; and $(\mathrm{g})$ the isoleucine AID\% $(P<0.01)$ in the 0Vit.C +10 Saff. Oil, 400Vit.C +5 Saff. Oil, and the 400Vit.C + 10 Saff. Oil groups; and $(\mathrm{g})$ the valine AID\% $(P=0.00)$ in the 400Vit.C + 5 Saff. oil and 400Vit.C + 10 Saff. Oil groups. The interaction resulted in a significant decrease in the 0Vit.C + 5 Saff. Oil group.

\section{Histological findings}

Sections from the duodenal segments displayed (i) short and thick villi with limited goblet cell metaplasia besides increased inflammatory cells in the lamina propria in the OVit.C+ OSaff. Oil group; (ii) tall and thin villi with few broad tips in certain villi without goblet cell metaplasia in the 0Vit.C + 5 Saff. Oil group; (iii) marked broad tips

Table 2 The effect of inclusion of safflower oil and vitamin C in the broiler chicken diet on the apparent ileal digestibility coefficient (AID\%) of amino acids

\begin{tabular}{|c|c|c|c|c|c|c|c|c|c|c|c|c|c|c|c|}
\hline \multirow[t]{2}{*}{ Item } & \multicolumn{2}{|c|}{$\begin{array}{l}\text { Vitamin C level } \\
\text { (mg/kg diet) }\end{array}$} & \multicolumn{3}{|c|}{$\begin{array}{l}\text { Safflower oil level } \\
(\mathrm{gm} / \mathrm{kg})\end{array}$} & \multicolumn{6}{|c|}{ Vitamin C $\times$ Safflower oil } & \multirow[t]{2}{*}{ SEM } & \multicolumn{3}{|l|}{ P-value } \\
\hline & 0 & 400 & 0 & 5 & 10 & $\begin{array}{l}\text { oVit.C+ } \\
0 \text { Saff. } \\
\text { Oil }\end{array}$ & $\begin{array}{l}\text { OVit.C + } \\
5 \text { Saff. } \\
\text { Oil }\end{array}$ & $\begin{array}{l}\text { OVit.C+ } \\
10 \text { Saff. } \\
\text { Oil }\end{array}$ & $\begin{array}{l}\text { 400Vit.C+ } \\
0 \text { Saff. Oil }\end{array}$ & $\begin{array}{l}\text { 400Vit.C+ } \\
5 \text { Saff. Oil }\end{array}$ & $\begin{array}{l}\text { 400Vit.C+ } \\
10 \text { Saff. Oil }\end{array}$ & & Vit. C & Saff. oil & $\begin{array}{l}\text { Vit.C x } \\
\text { Saff. oil }\end{array}$ \\
\hline Lysine & $88.54^{b}$ & $88.91^{a}$ & 88.78 & 88.78 & 88.61 & $88.40^{d}$ & $88.66^{c}$ & $88.57^{\mathrm{cd}}$ & $89.16^{a}$ & $88.91^{b}$ & $88.66^{c}$ & 0.16 & $<0.01$ & 0.46 & $<0.01$ \\
\hline Methionine & 84.51 & 84.10 & $83.96^{b}$ & $84.06^{\mathrm{ab}}$ & $84.90^{\mathrm{a}}$ & $83.54^{c}$ & $84.79^{b}$ & $85.21^{a}$ & $84.38^{b}$ & $83.33^{c}$ & $84.58^{b}$ & 0.06 & 0.22 & 0.03 & $<0.01$ \\
\hline Threonine & $84.69^{b}$ & $85.27^{\mathrm{a}}$ & 85.12 & 84.94 & 84.88 & $85.19^{a b}$ & $84.57^{c}$ & $84.32^{c}$ & $85.06^{b}$ & $85.31^{\mathrm{ab}}$ & $85.43^{a}$ & 0.10 & $<0.01$ & 0.60 & $<0.01$ \\
\hline Tryptophan & $86.54^{b}$ & $87.99^{\mathrm{a}}$ & 87.27 & 87.03 & 87.51 & $87.03^{b c d}$ & $86.06^{d}$ & $86.54^{\mathrm{cd}}$ & $87.51^{\mathrm{abc}}$ & $87.99^{a b}$ & $88.47^{\mathrm{a}}$ & 0.22 & $<0.01$ & 0.70 & $<0.01$ \\
\hline Arginine & $89.05^{b}$ & $89.31^{a}$ & 89.29 & 89.08 & 89.16 & $89.08^{b c}$ & $88.99^{c}$ & $89.08^{b c}$ & $89.51^{\mathrm{a}}$ & $89.16^{b c}$ & $89.25^{b}$ & 0.04 & $<0.01$ & 0.13 & $<0.01$ \\
\hline Valine & $84.61^{b}$ & $85.13^{a}$ & 84.83 & 84.78 & 85.00 & $84.83^{b}$ & $84.39^{c}$ & $84.61^{b c}$ & $84.83^{b}$ & $85.16^{a}$ & $85.38^{a}$ & 0.06 & $<0.01$ & 0.55 & $<0.01$ \\
\hline Leucine & 90.07 & 90.16 & $90.21^{\mathrm{a}}$ & $90.13^{a b}$ & $90.01^{b}$ & $90.05^{b}$ & $90.11^{b}$ & $90.00^{b}$ & $90.37^{a}$ & $90.11^{b}$ & $90.02^{b}$ & 0.03 & 0.15 & $<0.01$ & $<0.01$ \\
\hline Isoleucine & 85.07 & 85.23 & $84.91^{b}$ & $85.09^{b}$ & $85.45^{\mathrm{a}}$ & $84.91^{b}$ & $84.91^{b}$ & $85.39^{a}$ & $84.91^{b}$ & $85.27^{a}$ & $85.51^{a}$ & 0.08 & 0.22 & $<0.01$ & $<0.01$ \\
\hline
\end{tabular}

$\mathrm{a}, \mathrm{b}, \mathrm{c}$ Means within the same row carrying different superscripts are significantly different at $(P<0.05)$ 
and serrated surfaces with marked goblet cell metaplasia besides mild adhesions in the 0Vit.C+10Saff. Oil group. The duodenal sections from the 400Vit.C + OSaff. Oil, 400Vit.C + 5Saff. Oil, and 400Vit.C + 10Saff. Oil groups appeared healthier and were characterized by a gradual increase in tall and thin villi without goblet cell metaplasia. The exception was an increased infiltration of the intra-epithelial lymphocytic lick cells in the 400Vit.C+ 10Saff. Oil group (Fig. 1).

Sections from the jejunal segments displayed some denuded villi parts in the lumen besides marked adhesions of the villi in both 0Vit.C+ OSaff. Oil and 0Vit.C + 5 Saff. Oil groups. A gradual increase was observed in the tall villi in each of the 0Vit.C+10Saff. Oil, 400Vit.C+0Saff. Oil, 400Vit.C + 5Saff. Oil, and the 400Vit.C+ 10Saff. Oil groups, respectively (Fig. 2).

Sections from the ileal segments displayed (i) short and thick villi with increased goblet cell metaplasia and hypertrophic enterocytes in the 0Vit.C+ OSaff. Oil, 0Vit.C + 5Saff. Oil, and 0Vit.C+10Saff. Oil groups; (ii) severe acute associated lymphocytic aggregations (Peyer's Patches) with necrotic parts in the 400Vit.C + OSaff. Oil group; and (iii) tall and thin villi with increased absorptive surfaces represented by broad tips and serrated surfaces due to increased proliferating enterocytes in both the 400Vit.C+5Saff. Oil and the 400Vit.C+ 10Saff. Oil groups (Fig. 3).

\section{Morphometric measures of the small intestine}

The effect of vitamin $C$ on the morphometric measures of the intestine is shown in Table 3. Dietary supplementation with $400 \mathrm{mg} / \mathrm{kg}$ diet of vitamin $C$ resulted in a significant increase $(P<0.05)$ in the duodenal and jejunal mucosal depth and ileal crypt depth. Moreover, it caused a significant decrease $(P<0.05)$ in the duodenal and jejunal goblet cell count and intra-epithelium lymphocytic lick cells infiltration and decreased the jejunal and ileal villous height/crypt depth ratio significantly $(P<0.05)$ when compared to the measurements in the nonsupplemented diet.

The duodenal villous height was significantly increased $(P<0.05)$ in the 5 and 10saff. Oil groups compared to that in the 0saff. Oil group. Dietary supplementation with 5saff. Oil resulted in a significant increase $(P<0.05)$ in the duodenal crypt depth and mucosal thickness compared to that in the 0saff.oil group. There was a significant increase $(P<0.05)$ in the duodenal goblet cell count in the 10saff.oil group compared to that in the 0saff. Oil group. A significant increase $(P<0.05)$ in the jejunal villous width and crypt depth was found in the 5 and 10saff. Oil groups compared to that observed in the 0saff. Oil group. Dietary supplementation with 5 and 10saff. Oil resulted in a significant increase $(P<0.05)$ in the ileal villous height, crypt depth, and mucosal thickness compared to that in the 0saff.oil group. A significant increase in the ilea villous width $(P<0.05)$ was found in 10saff. Oil group, and a significant increase in the ilea goblet cell count $(P<0.05)$ was found in 5saff.oil group compared to the 0saff.oil group. Safflower supplementation at both levels decreased the villous height/crypt depth ratio significantly $(P<0.05)$ in all small intestine parts compared to that observed in the non-supplemented diet.

The interaction between vitamin $C$ and safflower oil resulted in a significant increase $(P<0.01)$ in (i) the duodenal villous height in the 0Vit.C +5 saff. Oil and

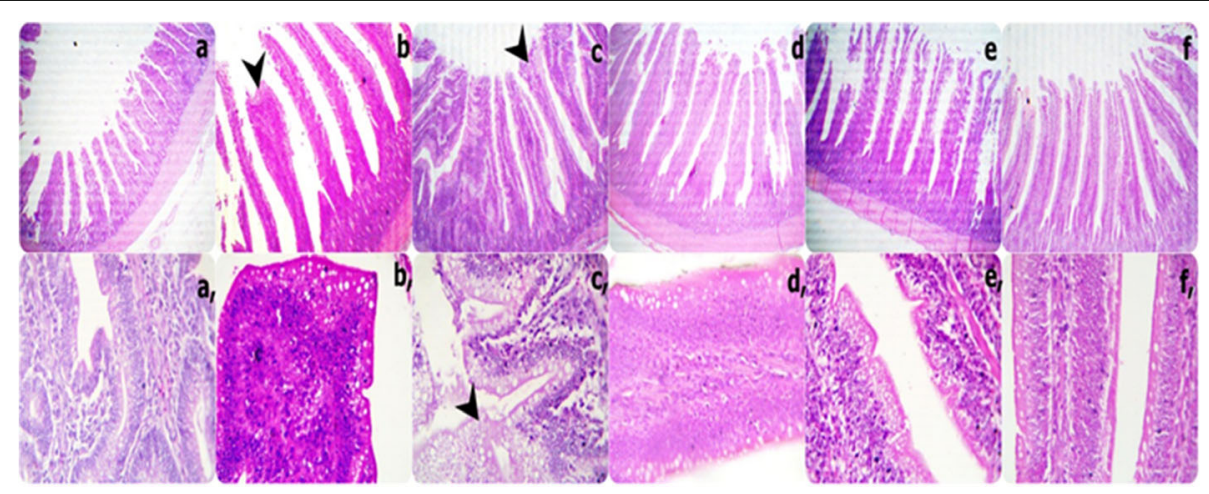

Fig. 1 Representative photomicrograph of the low (40X) and high (400X) magnification H\&E stained duodenums segment sections showing short and thick villi with limitation goblet cell metaplasia besides increasing inflammatory cells in the lamina propria in OVit.C+ OSaff. Oil group; tall and thin villi with a few broad tips in a few villi without goblet cell metaplasia in OVit.C + 5 Saff. Oil group; marked brad tips and serrated surfaces with marked goblet cell metaplasia besides mild adhesions in OVit.C+ 10Saff. Oil group; more healthy which characterized by gradual increase tall and thin villi without goblet cells metaplasia in each 400Vit.C + 0Saff. Oil, 400Vit.C+5Saff. Oil, and 400Vit.C+ 10Saff. Oil groups respectively except increase intra-epithelium lymphocytic lick cells infiltrations in 400Vit.C+ 10Saff. Oil group. (a and a: 0Vit.C+ 0Saff. Oil group, b, and b: OVit.C+ 5 Saff. Oil group, c, and c:OVit.C+ 10Saff. Oil group: $d$ and d: 400Vit.C+ 0Saff. Oil, e and e: 400Vit.C + 5Saff. Oil, f and f: 400Vit.C+ 10Saff. Oil group) 


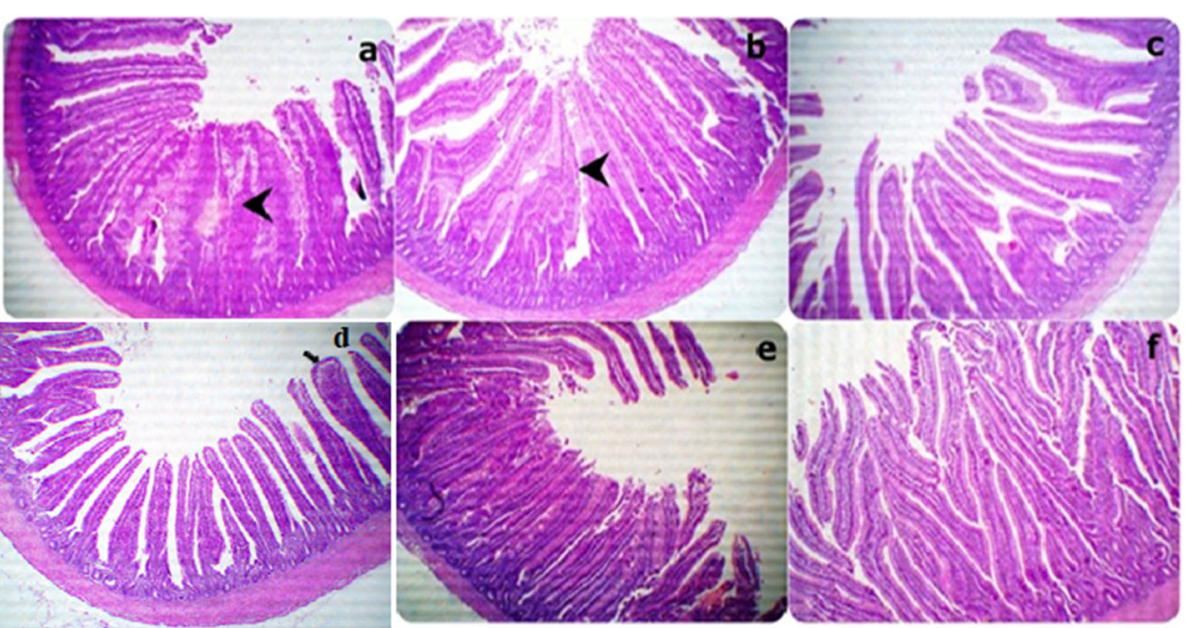

Fig. 2 Representative photomicrograph of the (40X) magnification H\&E stained jejunum segment sections showing a little denuded villi parts in the lumen beside marked adhesions of the villi in both $a$ and $b$ groups: gradually increased of the tall villi in each $c, d$, e and $f$ groups respectively. (a: OVit.C+ OSaff. Oil group, b: OVit.C + 5 Saff. Oil group, c: OVit.C+ 10Saff. Oil group: d: 400Vit.C + 0Saff. Oil, e: 400Vit.C + 5Saff. Oil, f: 400Vit.C+ 10Saff. Oil group)

400Vit.C + 10saff. Oil groups; (ii) the duodenal villous width in the 0Vit.C + 5saff. Oil and 0Vit.C + 10saff. Oil groups; and (iii) the duodenal crypt depth and mucosal thickness in all the experimental groups compared to the 0Vit.C + 0saff. oil group. However, the highest crypt depth and mucosal thickness were found in the 0Vit.C + 5 saff. Oil group. Moreover, the interaction between vitamin $C$ and safflower oil resulted in a significant increase $(P<0.01)$ in (iv) the duodenal goblet cell count in the 0 Vit.C +10 saff. Oil group and (v) the duodenal intraepithelium lymphocytic lick cells infiltrations in the 0Vit.C + 5saff. Oil group compared to the 0Vit.C + 0saff. Oil group; (vi) the jejunal villus width, crypt depth, and mucosal thickness in all diets that included vitamin $\mathrm{C}$ and safflower oil compared to the 0Vit.C + Osaff. Oil group; (vii) the jejunal intra-epithelium lymphocytic lick cells infiltration in the 0Vit.C + 5saff. Oil and 0Vit.C + 10saff. Oil groups compared to the 0Vit.C +0 saff. Oil group; (viii); the ileal villous height in the $0 \mathrm{Vit} . \mathrm{C}+10$ saff. Oil and 400Vit.C+10saff. Oil groups; (ix) the ileal villus width, crypt depth, and mucosal thickness in all experimental groups compared to the 0Vit.C + 0saff. Oil group; and $(\mathrm{x})$ the ileal intra-epithelium lymphocytic lick cells infiltration in the 400Vit.C + 0saff. Oil group compared to the OVit.C + 0saff. Oil group. However, a significant decrease $(P<0.01)$ in the jejunal goblet cell count was

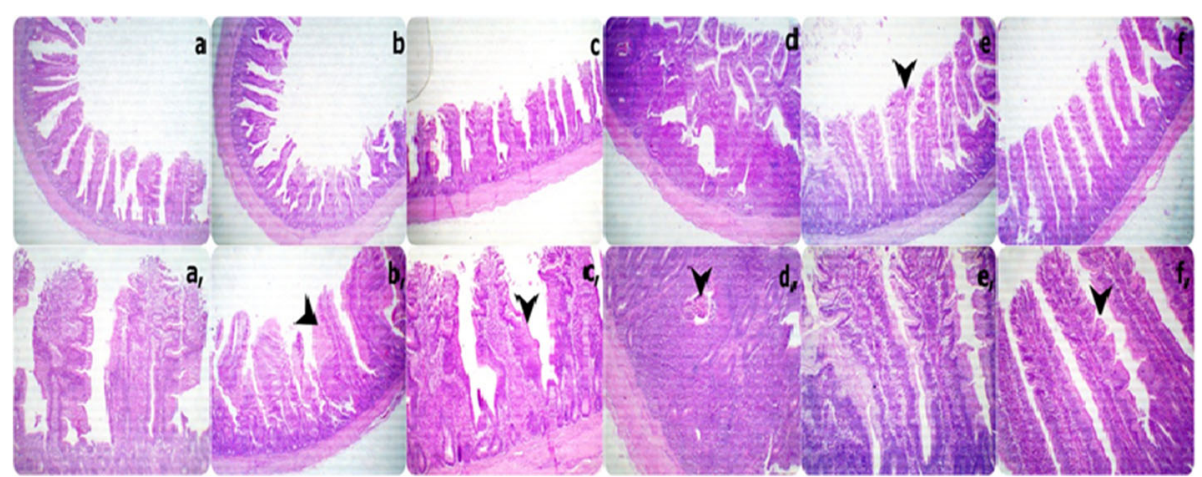

Fig. 3 Representative photomicrograph of the low (40X) and high (100X) magnification H\&E stained ileum segment sections showing short and thick villi with increase goblet cells metaplasia with hypertrophic enterocytes $\mathbf{a}, \mathbf{b}$ and $\mathbf{c}$ groups: severe active associated lymphocytic aggregations (Pyre's Patches) with necrotic parts (arrowhead) in d group: tall and thin villi with increase absorptive surfaces which represented by brad tips and serrated surfaces due to increase proliferated enterocytes (arrowhead) in both e and f groups. (a and a: OVit.C+ 0Saff. Oil group, b, and b: OVit.C+ 5 Saff. Oil group, c, and c: OVit.C+ 10Saff. Oil group: $d$ and d: 400Vit.C+ 0Saff. Oil, e and e: 400Vit.C+5Saff. Oil, f and f: 400Vit.C+ 10Saff. Oil group) 


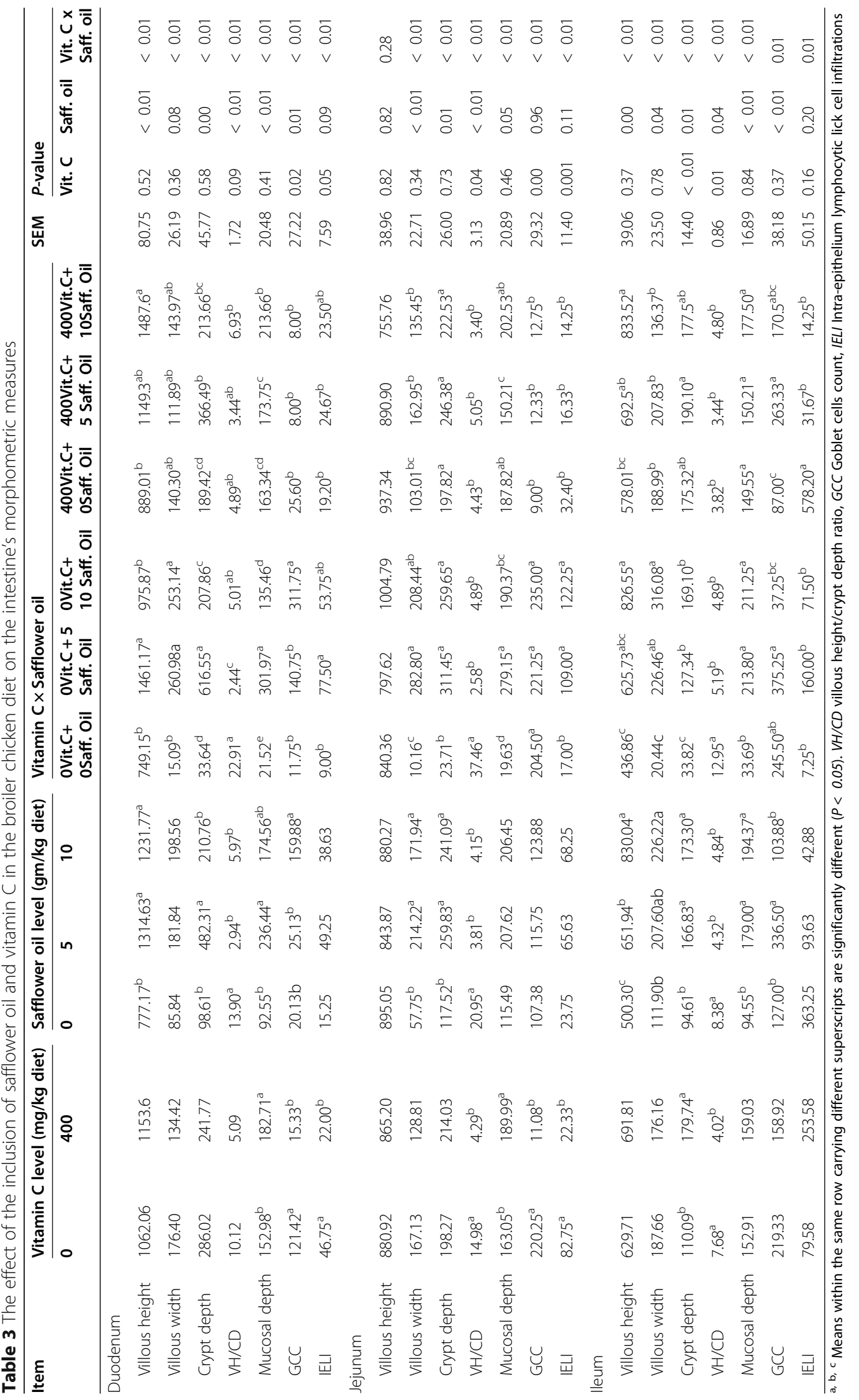


observed in the 400Vit.C + 0saff.Oil, 400Vit.C + 5saff.Oil, and 400Vit.C + 10saff.oil groups. Also, a significant decrease $(P=0.01)$ was observed in the ileal goblet cell count in the 400Vit.C+0saff. Oil group; The villous height/crypt depth ratio $(P<0.05)$ was decreased in the duodenum in the 0Vit.C + 5saff.Oil and 400Vit.C + 10saff. Oil groups and in the jejunum and ileum in all experimental groups compared with the $0 \mathrm{Vit}$. C + Osaff.Oil group.

\section{Carcass traits}

The carcass traits represented as "\% relative to the carcass weight" are shown in Table 4. The intestinal weight increased significantly $(P<0.01)$ in the birds fed a diet supplemented with $400 \mathrm{mg} / \mathrm{kg}$ diet of vitamin $C$ alone or in combination with a $10 \mathrm{~g}$ safflower oil $/ \mathrm{kg}$ diet. The weight of the thymus and the bursa of Fabricius significantly increased $(P<0.05)$ after the dietary inclusion of vitamin $C$ alone. The liver weight increased significantly $(P<0.01)$ in the group of birds fed a diet containing $5 \mathrm{~g}$ safflower oil $/ \mathrm{kg}$. Dietary inclusion of safflower oil and vitamin $C$ had no significant effect on the gizzard, spleen, heart, and carcass weights $(P>0.05)$.

\section{Behavioral observations}

The effect of dietary supplementation with safflower oil and vitamin $C$ on the broilers' behavior is represented in Table 5. The results showed that the feeding, resting, and comfort behavior significantly increased $(P<0.05)$ in the birds fed a diet supplemented with vitamin $C$ than in the birds fed a non-supplemented diet. The birds fed on a diet supplemented with vitamin $C$ engaged in significantly less feather pecking $(P=0.02)$. Dietary inclusion of Safflower oil had a positive effect on most of the observed behaviors. The feather preening (comfort behavior) was significantly increased in the group fed a diet enriched with vitamin $C$ and safflower oil $(P=0.04)$.

\section{Fatty acid composition of the breast muscle}

Table 6 highlights the effect of dietary inclusion of safflower oil and vitamin $\mathrm{C}$ on the breast muscle's fatty acid composition. In general, safflower oil inclusion resulted in a significant increase $(P<0.05)$ in the levels of stearic acid, linoleic acid, saturated fatty acids, and omega-3 fatty acids. Meanwhile, the omega-3/omega- 6 fatty acids ratio " $\omega-3 / \omega-6$ ratio" increased $(P=0.01)$ only in the group fed a diet containing $10 \mathrm{~g}$ of safflower oil $/ \mathrm{kg}$ diet. The inclusion of vitamin $C$ had no significant effect $(P>$ 0.05 ) on the fatty acid composition of the breast muscle.

\section{Blood biochemical parameters}

The effect of dietary inclusion of safflower oil and vitamin $C$ on the antioxidant defense system, selective immunological parameters, and liver and kidney function tests is shown in Table 7. In the current study, the birds' antioxidant status was assessed by measuring the serum levels of CAT and SOD and the breast muscle concentration of GSH and MDA. The results revealed a significant increase $(P<0.05)$ in the serum levels of CAT, $\mathrm{SOD}$, and GSH in the vitamin $\mathrm{C}$-supplemented diets. Safflower oil inclusion had no significant effect $(P>0.05)$ on these previously mentioned parameters. The interaction between vitamin $C$ and safflower oil did not cause any significant effect $(P>0.05)$ on these parameters. The muscle MDA level was decreased significantly $(P<0.01)$ by safflower oil inclusion. Interaction between vitamin $\mathrm{C}$ and safflower oil resulted in a significant decrease $(P<$ 0.01 ) in the MDA level in the muscles of birds fed diets supplemented with safflower oil and vitamin C.

The immunological parameters represented by the serum levels of IgA and complement C3 were also assessed. The dietary inclusion of vitamin $\mathrm{C}$ resulted in significantly higher levels $(P<0.01)$ of these two components. The interaction between vitamin $C$ and safflower oil resulted in a significant increase $(P<0.05)$ in the serum levels of IgA and complement C3 in the birds fed

Table 4 The effect of inclusion of safflower oil and vitamin C in the broiler chicken diet on the carcass traits \% relative to the live body weight

\begin{tabular}{|c|c|c|c|c|c|c|c|c|c|c|c|c|c|c|c|}
\hline \multirow[t]{2}{*}{ Item } & \multicolumn{2}{|c|}{$\begin{array}{l}\text { Vitamin C level } \\
\text { (mg/kg diet) }\end{array}$} & \multicolumn{3}{|c|}{$\begin{array}{l}\text { Safflower oil level } \\
\text { (gm/kg diet) }\end{array}$} & \multicolumn{6}{|c|}{ Vitamin $\mathrm{C} \times$ Safflower oil } & \multirow[t]{2}{*}{ SEM } & \multicolumn{3}{|l|}{ P-value } \\
\hline & 0 & 400 & 0 & 5 & 10 & $\begin{array}{l}\text { OVit.C+ } \\
\text { OSaff. Oil }\end{array}$ & $\begin{array}{l}\text { oVit.C }+5 \\
\text { Saff. Oil }\end{array}$ & $\begin{array}{l}\text { OVit.C+ } 10 \\
\text { Saff. Oil }\end{array}$ & $\begin{array}{l}\text { 400Vit.C+ } \\
\text { 0Saff. Oil }\end{array}$ & $\begin{array}{l}\text { 400Vit.C+ } \\
5 \text { Saff. Oil }\end{array}$ & $\begin{array}{l}\text { 400Vit.C+ } \\
\text { 10Saff. Oil }\end{array}$ & & Vit. C & $\begin{array}{l}\text { Saff. } \\
\text { oil }\end{array}$ & $\begin{array}{l}\text { Vit. C x } \\
\text { Saff. oil }\end{array}$ \\
\hline Intestine & 5.95 & 6.40 & 5.85 & 6.16 & 6.53 & $5.13^{b}$ & $6.43^{a b}$ & $6.28^{\mathrm{ab}}$ & $6.55^{\mathrm{a}}$ & $5.87^{\mathrm{ab}}$ & $6.77^{\mathrm{a}}$ & 0.16 & 0.17 & 0.32 & 0.01 \\
\hline Spleen & 0.10 & 0.11 & 0.09 & .011 & 0.11 & 0.09 & 0.09 & 0.10 & 0.08 & 0.13 & 0.11 & 0.008 & 0.50 & 0.41 & 0.67 \\
\hline Bursa & $0.11^{\mathrm{a}}$ & $0.16^{\mathrm{a}}$ & $0.17^{a}$ & $0.12^{\mathrm{ab}}$ & $0.11^{b}$ & $0.15^{\mathrm{ab}}$ & $0.08^{b}$ & $0.08^{b}$ & $0.18^{\mathrm{a}}$ & $0.15^{\mathrm{ab}}$ & $0.13^{a b}$ & 0.01 & $<0.01$ & 0.04 & $<0.01$ \\
\hline Thymus & $0.43^{b}$ & $0.57^{a}$ & 0.4 & 0.50 & 0.51 & $0.33^{b}$ & $0.43^{a b}$ & $0.51^{\mathrm{ab}}$ & $0.62^{a}$ & $0.56^{\mathrm{ab}}$ & $0.51^{a b}$ & 0.02 & 0.01 & 0.90 & 0.03 \\
\hline Gizzard & 2.72 & 2.43 & 2.46 & 2.59 & 2.66 & 2.48 & 2.93 & 2.73 & 2.44 & 2.25 & 2.58 & 0.07 & 0.05 & 0.58 & 0.09 \\
\hline Liver & 2.20 & 2.09 & $2.08^{b}$ & $2.44^{\mathrm{a}}$ & $1.90^{\mathrm{b}}$ & $2.03^{b c}$ & $2.56^{\mathrm{a}}$ & $1.99^{b c}$ & $2.13^{\mathrm{abc}}$ & $2.32^{\mathrm{ab}}$ & $1.80^{c}$ & 0.06 & 0.44 & $<0.01$ & $<0.01$ \\
\hline Carcass & 63.60 & 63.15 & 63.93 & 62.75 & 63.45 & 64.81 & 61.93 & 64.05 & 63.04 & 63.56 & 62.85 & 0.41 & 0.60 & 0.53 & 0.47 \\
\hline Heart & 0.43 & 0.45 & 0.46 & 0.42 & 0.45 & 0.42 & 0.42 & 0.45 & 0.49 & 0.41 & 0.45 & 0.01 & 0.66 & 0.60 & 0.81 \\
\hline
\end{tabular}

a, b, c Means within the same row carrying different superscripts are significantly different at $(P<0.05)$ 
Table 5 The effect of inclusion of safflower oil and vitamin $C$ in the broiler chicken diet on the behavioral activities

\begin{tabular}{|c|c|c|c|c|c|c|c|c|c|c|c|c|c|c|c|}
\hline & \multicolumn{2}{|c|}{$\begin{array}{l}\text { Vitamin C level } \\
\text { (mg/kg diet) }\end{array}$} & \multicolumn{3}{|c|}{$\begin{array}{l}\text { Safflower oil level } \\
(\mathbf{g} / \mathbf{k g})\end{array}$} & \multicolumn{6}{|c|}{ Vitamin C $\times$ Safflower oil } & \multirow[t]{2}{*}{ SEM } & \multicolumn{3}{|c|}{$P$-value } \\
\hline & 0 & 400 & 0 & 5 & 10 & $\begin{array}{l}\text { OVit.C+ } 0 \\
\text { Saff. Oil }\end{array}$ & $\begin{array}{l}\text { OVit.C }+5 \\
\text { Saff. Oil }\end{array}$ & $\begin{array}{l}\text { OVit.C+ } 10 \\
\text { Saff. Oil }\end{array}$ & $\begin{array}{l}\text { 400Vit.C+ } \\
\text { 0 Saff. } \\
\text { Oil }\end{array}$ & $\begin{array}{l}\text { 400Vit.C+ } \\
5 \text { Saff. } \\
\text { Oil }\end{array}$ & $\begin{array}{l}\text { 400Vit.C+ } \\
10 \text { Saff. } \\
\text { Oil }\end{array}$ & & Vit. C & Saff. oil & $\begin{array}{l}\text { Vit. C } x \\
\text { Saff. oil }\end{array}$ \\
\hline Feeding & $48.99^{b}$ & $79.86^{a}$ & $48.76^{b}$ & $62.56^{\mathrm{ab}}$ & $81.93^{a}$ & 32.27 & 49.96 & 64.76 & 65.28 & 75.15 & 99.15 & 9.6 & 0.001 & 0.015 & 0.89 \\
\hline Drinking & 33.85 & 37.82 & $28.44^{b}$ & $24.35^{\mathrm{b}}$ & $54.71^{\mathrm{a}}$ & 32.22 & 16.65 & 52.68 & 24.67 & 32.06 & 56.73 & 8.51 & 0.6 & 0.003 & 0.49 \\
\hline Resting & $129.6^{\mathrm{b}}$ & $211.04^{\mathrm{a}}$ & $115.94^{b}$ & $172.9^{\mathrm{b}}$ & $222.12^{\mathrm{a}}$ & 70.28 & 148.5 & 170.21 & 161.6 & 197.48 & 274.03 & 12.55 & $<0.01$ & $<0.01$ & 0.41 \\
\hline Standing & 53.65 & 44.4 & $68.69^{\mathrm{a}}$ & $51.26^{\mathrm{ab}}$ & $27.12^{\mathrm{b}}$ & 81.88 & 42.1 & 36.98 & 55.51 & 60.43 & 17.27 & 10.6 & 0.33 & 0.003 & 0.12 \\
\hline Walking & 46.44 & 47.27 & 50.08 & 54.74 & 35.76 & $32.33^{b}$ & $62.61^{\mathrm{a}}$ & $44.40^{\mathrm{b}}$ & $67.83^{\mathrm{a}}$ & $46.86^{\mathrm{b}}$ & $27.13^{b}$ & 9.2 & 0.9 & 0.15 & 0.02 \\
\hline $\begin{array}{l}\text { Feather } \\
\text { preening }\end{array}$ & $27.99^{\mathrm{b}}$ & $57.97^{\mathrm{a}}$ & $30.89^{b}$ & $45.63^{\mathrm{ab}}$ & $52.42^{\mathrm{a}}$ & $24.78^{b}$ & $33.3^{b}$ & $25.9^{b}$ & $37.0^{b}$ & $57.96^{\mathrm{ab}}$ & $78.94^{\mathrm{a}}$ & 7.2 & $<0.01$ & 0.03 & 0.04 \\
\hline $\begin{array}{l}\text { Others } \\
\text { comfort }\end{array}$ & $15.77^{b}$ & $34.94^{\mathrm{a}}$ & 23.35 & 28.59 & 27.13 & 15.87 & 16.65 & 14.8 & 30.83 & 34.53 & 39.46 & 5.9 & $<0.01$ & 0.85 & 0.75 \\
\hline Foraging & 25.56 & 26.72 & $35.95^{a}$ & $30.76^{\mathrm{a}}$ & $11.7^{b}$ & 29.98 & 43.02 & 3.68 & 41.93 & 18.5 & 19.73 & 3.58 & 0.86 & 0.01 & 0.02 \\
\hline $\begin{array}{l}\text { Feather } \\
\text { pecking }\end{array}$ & 5.45 & 1.64 & 5.89 & 2.75 & 1.99 & 8.09 & 5.5 & 2.76 & 3.68 & 0.62 & 1.23 & 0.65 & 0.02 & 0.147 & 0.59 \\
\hline
\end{tabular}

$\overline{\mathrm{a}, \mathrm{b}}$ Means within the same row carrying different superscripts are significantly different $(P<0.05)$

a diet supplemented with 400vit.C + 10 Saff. Oil (400 mg vitamin $\mathrm{C} / \mathrm{kg}$ diet+ $10 \mathrm{~g}$ safflower Oil/kg diet). The serum levels of cortisone, ALT, AST, urea, and creatinine were not significantly $(P>0.05)$ affected by the dietary inclusion of safflower oil and vitamin $C$.

\section{Discussion}

This study assessed the effect of safflower oil and vitamin $\mathrm{C}$ inclusion in the broiler chicken diets on the growth performance, behavior, amino acids AID\%, carcass traits, the fatty acid composition of breast

Table 6 The effect of inclusion of safflower oil and vitamin C in the broiler chicken diet on the fatty acid composition of the breast muscle (\% of total fatty acids)

\begin{tabular}{|c|c|c|c|c|c|c|c|c|c|c|c|c|c|c|c|}
\hline \multirow[t]{2}{*}{ Item } & \multicolumn{2}{|c|}{$\begin{array}{l}\text { Vitamin C level } \\
\text { (mg/kg diet) }\end{array}$} & \multicolumn{3}{|c|}{$\begin{array}{l}\text { Safflower oil level } \\
\text { (gm/kg diet) }\end{array}$} & \multicolumn{6}{|c|}{ Vitamin C $\times$ Safflower oil } & \multirow[t]{2}{*}{ SEM } & \multicolumn{3}{|c|}{$P$-value } \\
\hline & 0 & 400 & 0 & 5 & 10 & $\begin{array}{l}\text { OVit.C+ } \\
\text { OSaff. Oil }\end{array}$ & $\begin{array}{l}\text { oVit.C }+5 \\
\text { Saff. Oil }\end{array}$ & $\begin{array}{l}\text { OVit.C+ } 10 \\
\text { Saff. Oil }\end{array}$ & $\begin{array}{l}\text { 400Vit.C+ } \\
\text { 0Saff. Oil }\end{array}$ & $\begin{array}{l}\text { 400Vit.C+ } \\
5 \text { Saff. } \\
\text { Oil }\end{array}$ & $\begin{array}{l}\text { 400Vit.C+ } \\
\text { 10Saff. } \\
\text { Oil }\end{array}$ & & $\begin{array}{l}\text { Vit. } \\
\text { C }\end{array}$ & $\begin{array}{l}\text { Saff. } \\
\text { oil }\end{array}$ & $\begin{array}{l}\text { Vit. C x } \\
\text { Saff. oil }\end{array}$ \\
\hline C14:0 & 0.13 & 0.14 & 0.13 & 0.14 & 0.15 & 0.12 & 0.14 & 0.14 & 0.14 & 0.15 & 0.15 & 0.01 & 0.40 & 0.40 & 0.79 \\
\hline C16:0 & 2.60 & 2.64 & 2.51 & 2.66 & 2.69 & 2.48 & 2.65 & 2.68 & 2.54 & 2.66 & 2.70 & 0.20 & 0.84 & 0.64 & 0.97 \\
\hline C16:1 & 1.07 & 1.08 & 1.05 & 1.09 & 1.09 & 1.04 & 1.09 & 1.08 & 1.06 & 1.09 & 1.10 & 0.04 & 0.74 & 0.45 & 0.89 \\
\hline C18:0 & 1.17 & 1.21 & $1.11^{\mathrm{b}}$ & $1.22^{\mathrm{a}}$ & $1.23^{\mathrm{a}}$ & 1.08 & 1.21 & 1.21 & 1.15 & 1.22 & 1.25 & 0.04 & 0.29 & 0.01 & 0.07 \\
\hline C18:1 & 5.06 & 5.17 & 5.09 & 5.11 & 5.14 & 5.00 & 5.07 & 5.09 & 5.18 & 5.15 & 5.18 & 0.25 & 0.49 & 0.97 & 0.99 \\
\hline C18:2 & 2.02 & 2.06 & $1.96^{\mathrm{b}}$ & $2.07^{a}$ & $2.08^{\mathrm{a}}$ & 1.93 & 2.06 & 2.06 & 2.00 & 2.07 & 2.10 & 0.04 & 0.29 & 0.01 & 0.07 \\
\hline C18:3 & 0.16 & 0.24 & 0.12 & 0.23 & 0.24 & 0.06 & 0.20 & 0.21 & 0.18 & 0.26 & 0.27 & 0.04 & 0.07 & 0.06 & 0.08 \\
\hline C20:4 & 0.08 & 0.10 & 0.08 & 0.10 & 0.11 & 0.06 & 0.09 & 0.10 & 0.09 & 0.10 & 0.11 & 0.02 & 0.36 & 0.52 & 0.82 \\
\hline SFA & 4.13 & 4.18 & $4.08^{b}$ & $4.18^{\mathrm{a}}$ & $4.20^{\mathrm{a}}$ & 4.04 & 4.17 & 4.18 & 4.12 & 4.20 & 4.21 & 0.04 & 0.23 & 0.01 & 0.08 \\
\hline MUFA & 6.23 & 6.39 & 6.18 & 6.35 & 6.41 & 6.10 & 6.27 & 6.32 & 6.26 & 6.42 & 6.49 & 0.25 & 0.46 & 0.66 & 0.94 \\
\hline PUFA & 2.16 & 2.25 & 0.41 & 0.43 & 0.50 & 2.05 & 2.19 & 2.25 & 2.16 & 2.28 & 2.31 & 0.23 & 0.67 & 0.78 & 0.98 \\
\hline$\omega-3$ & 0.13 & 0.19 & $0.09^{b}$ & $0.18^{\mathrm{a}}$ & $0.21^{\mathrm{a}}$ & $0.04^{b}$ & $0.15^{\mathrm{ab}}$ & $0.18^{\mathrm{a}}$ & $0.13^{\mathrm{ab}}$ & $0.20^{\mathrm{a}}$ & $0.24^{\mathrm{a}}$ & $0.02 \mathrm{a}$ & 0.06 & 0.01 & 0.006 \\
\hline$\omega-6$ & 2.04 & 2.06 & 2.02 & 2.06 & 2.07 & 2.01 & 2.03 & 2.07 & 2.03 & 2.08 & 2.07 & 0.22 & 0.91 & 0.97 & 1.00 \\
\hline $\begin{array}{l}\omega-3 / \\
\omega-6\end{array}$ & 0.07 & 0.10 & $0.04^{b}$ & $0.09^{\mathrm{ab}}$ & $0.11^{\mathrm{a}}$ & 0.02 & 0.09 & 0.10 & 0.07 & 0.10 & 0.12 & 0.01 & 0.22 & 0.01 & 0.07 \\
\hline$S / U$ & 0.49 & 0.49 & 0.50 & 0.49 & 0.49 & 0.50 & 0.50 & 0.49 & 0.49 & 0.49 & 0.48 & 0.02 & 0.69 & 0.91 & 0.99 \\
\hline
\end{tabular}

$\mathrm{a}_{\mathrm{b}} \mathrm{b}$ Means within the same row carrying different superscripts are significantly different at $(P<0.05)$

Myristic acid(C14:0), Palmitic acid (C16:0), Palmitoleic acid (C16:1), Stearic acid (C18:0), Vaccenic acid(C18:1), Linoleic acid (C18:2), a-Linolenic acid (C18:3),

Arachidonic acid (C20:4), SFA saturated fatty acids, MUFA monounsaturated fatty acids, PUFA polyunsaturated fatty acids, $\omega-3:$ mega -3 fatty acids, $\omega-6: 0$ mega -6 fatty acids, S/U saturated/unsaturated fatty acids, MDA malondialdehyde 


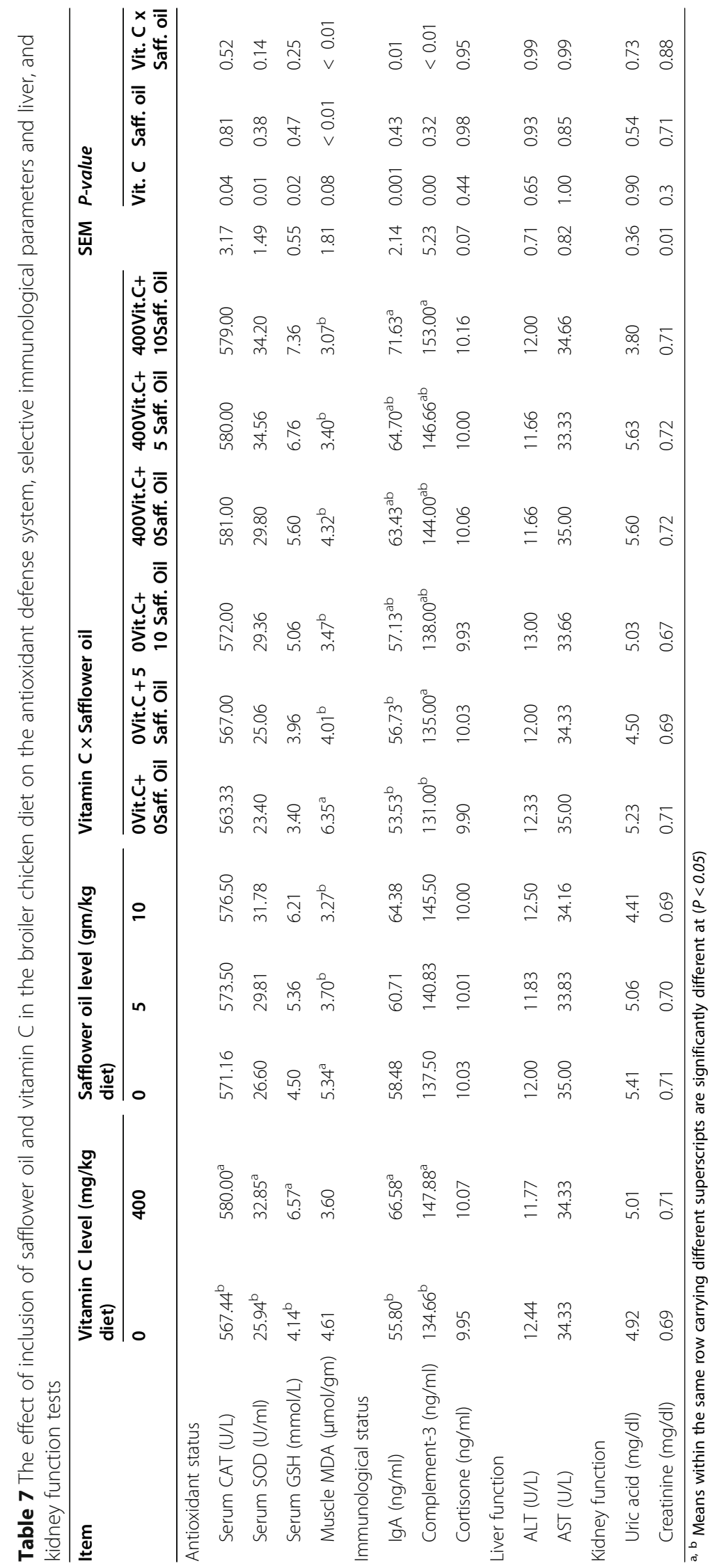


muscle, intestinal histology, immunological and antioxidant status of broiler chickens. The results revealed a positive effect of dietary inclusion of safflower oil and vitamin $\mathrm{C}$ on the BW, BWG, FI, and RGR of the broiler chickens. This may be attributed to the effect of their isolated or combined action on increasing the AID\% of amino acids, improving the intestinal health, and increasing its absorptive surface, as demonstrated in our study. Dietary supplementation with safflower oil and vitamin $\mathrm{C}$ improved the intestinal histology and increased the villous height and width, crypt depth, villous height/crypt depth ratio, mucosal thickness, goblet cell count, and intra-epithelium lymphocytic lick cells infiltrations. Absorptive efficiency is controlled by the condition of the intestinal absorptive surface. Morphologically, the crypt depth and intestinal villi length indicate the intestinal absorptive capacity [34]. Increased intestinal villi length leads to an increase in the mucosal surface area, and consequently, increased nutrient absorption [35-38]. The improved intestinal morphology observed in the current study may be attributed to the PUFA composition of safflower oil [39]. Moreover, ascorbic acid can affect intestinal health by enhancing tensile strength, epithelial formation, and internal protein flow $[40,41]$.

Several studies on rats and broilers investigated the effect of FA composition on fat digestibility. Better utilization and decreased fecal energy losses were reported from unsaturated fats compared to those from saturated fats. This resulted in an increased ME for the unsaturated fats [42-45] and additional energy utilization [46]. An expected higher fat deposition was observed due to the increased triglyceride storage in the adipose tissue. Shimomura, et al. [47] reported a decrease in the accumulated body fat in rats fed a diet supplemented with safflower oil compared to those fed a diet supplemented with beef tallow. Korver, et al. [48] observed an increase in the BWG in chicks fed diets containing safflower oil, tallow, and corn oil compared to those fed diets with cellulose and fish oil. Several studies reported an improved efficiency in broiler chickens' performance by the dietary supplementation of vitamin C [49-52]. Gouda, et al. [31] reported improvement in the growth performance, insulin growth factor 1, and thyroid hormone levels of the broilers by supplementing the diet with vitamin C $(200 \mathrm{mg} / \mathrm{kg})$ alone or along with folic acid $(1.5 \mathrm{mg} / \mathrm{kg})$. Sahin and Kucuk [53] stated that supplementation with $200 \mathrm{mg} / \mathrm{kg}$ diet of vitamin C, and not $100 \mathrm{mg} / \mathrm{kg}$ diet, resulted in increased FI, BW, and feed efficiency of Japanese quails. They also reported increased bird performance, nutrient digestibility, and carcass traits by dietary supplementation of vitamin $C$ and/or vitamin E. Ascorbic acid improved the feed efficiency by increasing the nutrient digestibility and controlling the deficiency of minerals and vitamins [54]. Dietary supplementation with vitamin $C$ increases the iron absorption by reducing $\mathrm{Fe}^{3+}$ to $\mathrm{Fe}^{2+}$, which is more absorbed by the intestine; thus, vitamin $\mathrm{C}$ increases the resistance to infections. Protein modifications caused by oxidative lesions may inhibit the pancreatic enzymes and dietary protein resistance to digestion. Hence, dietary supplementation with antioxidants such as vitamin $\mathrm{C}$ could prevent oxidative protein denaturation, and consequently, improve nutrient digestibility and feed efficiency [41, 55, 56]. Ciftci, et al. [57] demonstrated that ascorbate supplementation resulted in insignificant effects on birds' growth and egg production. They attributed this to the insufficiency of the vitamin $C$ dosage required to overcome heat stress. Moreover, improved FCR was reported in broilers subjected to heat stress after feeding them a vitamin C-supplemented diet [58, 59]. Attia, et al. [27] reported improvements in the BWG and FCR of heat-stressed broiler chickens by dietary supplementation of vitamin $\mathrm{C}$ alone and combination with vitamin $\mathrm{E}$ and probiotics.

Behavior is an important indicator for evaluating the well-being of animals. Our results showed the benefits of dietary supplementation of vitamin $C$ and safflower oil on the broiler chickens' behavioral observation and comfort level. Vitamin C supplementation improved their feeding behavior. Safflower oil inclusion improves the ingestive behavior (feeding and drinking). Chand, et al. [60] reported an increase in the feed intake of birds fed a diet enriched in ascorbic acid and Zn. El Iraqi, [61] stated that the patterns depicting comfort behavior increased by enrichment of the diet with anti-stress additive/s. Feather pecking in birds is considered a harmful activity. Our results revealed that enrichment of the diet with vitamin $C$ positively reduces this unfavorable behavior. The study of Nosrati, et al. [62] assessed the effect of adding vitamin $\mathrm{C}$, probiotics, antibiotics, herbal extract, and organic acid into the drinking water of broiler chickens and reported improved body weight of birds by supplementing the drinking water with vitamin $\mathrm{C}$ alone or with the antibiotic.

There is a great focus on researching foods containing polyunsaturated fatty acids at higher levels because of their benefits to human health [3, 6-8]. Raza, et al. [63] reported that supplementing the Hy-Line White Leghorn diet with a mixture of $25 \%$ hempseed and $2 \%$ turmeric and ginger enriched the egg yolk with PUFA, $\omega-3$, and $\omega-6$. The current study results indicated that safflower oil inclusion improved the fatty acid composition of the diet and increased the PUFA content of the breast muscle in the carcass. Birds cannot synthesize linoleic and linolenic acids. Hence, their occurrence and quantity in the body lipids depend on their supplementation through the diet and on the rate of tissue oxidation [64]. 
Kirchgessner, et al. [65] reported an increase in breast muscle fat content by increasing the dietary linoleic acid levels. Plant-rich oils contain high levels of polyunsaturated fatty acids (PUFA) but vary in essential FA composition. Kishawy, et al. [3] reported an increase in the alpha-linolenic acid content in the breast muscle of broiler chickens after replacing soybean oil with linseed oil in the diets. PUFA is incorporated in the phospholipids [66] of the muscle fat rather than adipose tissue fat [67]. PUFA feeding probably leads to increased dietary fatty acid oxidation as they increase the expression of acyl-CoA oxidase, the chief enzyme of $\beta$-oxidation, in the peroxisomes $[68,69]$. Further, PUFA oxidation results in internal fatty acid synthesis from carbohydrates; this incurs a greater energy expenditure than the direct deposition of fatty acids from the diet [70]. Hence, the dietary addition of antioxidants is required to prevent the $\beta$-oxidation of these FA.

One of the most important findings from our study was that the mixture of safflower oil and vitamin C combined both these supplements' features. The final product was an increased bodyweight that was enriched by essential fatty acids and antioxidant substances. A significant increase was observed in the serum levels of CAT, SOD, and GSH in chickens fed with vitamin Csupplemented diets in the current study. A significant decrease was observed in the MDA level in the muscles of birds fed diets supplemented with safflower oil and/or vitamin C. Ascorbate is involved in the regeneration of reduced glutathione from the oxidative form in the cytoplasm; it also aids in the regeneration of tocopherol through a non-enzymatic reaction [71]. Gouda, et al. [31] demonstrated an improved total antioxidant capacity, catalase activity, and SOD activity of broiler chickens under heat stress when they were fed a diet supplemented with vitamin C $(200 \mathrm{mg} / \mathrm{kg})$ alone or in combination with folic acid $(1.5 \mathrm{mg} / \mathrm{kg})$.

Similarly, dietary supplementation with Vitamin C reduced the serum level of MDA, as observed by Sahin, et al. [72]. Öztürk-Ürek, et al. [73] observed increased levels of SOD and GPx in adult chickens fed ascorbic acid-supplemented diets. Florou-Paneri, et al. [74] observed significantly lower MDA levels in the chilled tissue of raw breast muscles of chickens fed a vitamin Csupplemented diet.

The chicken immune response showed an improvement after dietary supplementation with vitamin $\mathrm{C}$ and with the combination of 400vit.C + 10 Saff. Oil; this is concluded from the higher serum levels of IgA and complement C3. Gouda, et al. [31] demonstrated an increased antibody titer against the Newcastle disease virus and decreased heterophil/lymphocytes in broiler chickens by supplemental vitamin $C(200 \mathrm{mg} / \mathrm{kg})$ alone or in combination with folic acid $(1.5 \mathrm{mg} / \mathrm{kg})$. Chand, et al. [60] observed that broiler chickens fed a diet supplemented with ascorbic acid, and $\mathrm{Zn}$ showed increased weights of the spleen, thymus, and bursa. They also reported an improvement in the cellular and humoral immunity in birds fed a diet supplemented with $300 \mathrm{mg} / \mathrm{kg}$ of ascorbic acid. Bendich [75] confirmed that ascorbic acid is necessary for the systemic availability of immunoglobulins and interferons. Additionally, ascorbic acid supplementation increased the levels of $\mathrm{CD}^{8+}$ and IgM [76]. Asli, et al. [77] reported an insignificant increase in the immune response by dietary supplementation of vitamin $\mathrm{C}$ and vitamin $\mathrm{E}$.

The enhanced immune status with vitamin $C$ supplementation can be attributed to its role in reducing the adrenocorticotropic hormone that has a suppressive and cytotoxic effect on the immune function [78]. Moreover, ascorbic acid increases the differentiation of the lymphoid organ by improving the activity of the hexose monophosphate pathway, which increases the production of antibodies [79]. Furthermore, the improved immune status can be attributed to the crucial role of PUFA composition in safflower oil that has been reported to have immune health-enhancing properties in poultry [80]. Dietary fat impacts the inflammatory response by modulating the production of cytokines [81]. Feeding with n-6 fatty acids increased the cell-mediated immune response, while $n-3$ fatty acids increased the antibody-mediated immune response [82].

Dietary supplementation with safflower oil and vitamin C did not affect the serum levels of cortisone, ALT, AST, urea, and creatinine. Similar results were reported in [83]. Similarly, Attia, et al. [27] reported no significant effect of vitamin supplementation on the serum levels of AST and ALT.

\section{Conclusions}

The current results indicated that a dietary combination of safflower oil and vitamin $\mathrm{C}$ improved the growth performance by improving the AID\% of amino acids and intestinal histology. This combination improved the immune status, antioxidant status, the ingestive, resting, and feather preening behavior of broiler chickens; the best supplementation level was 400vit.C + 10 Saff. Oil. Safflower oil inclusion increased stearic acid levels, linoleic acid, saturated fatty acids, and omega- 3 fatty acids in the breast muscle. This also leads to increased customer acceptance.

\section{Methods \\ Birds}

Three hundred 1-day-old chicks (Ross 308 broiler) were procured from a commercial chick producer (Dakahlia Poultry, Mansoura, Egypt) for the experiments. Before starting the investigation, they were subjected to a 3-day 
adaptation period. During this period, they were fed the control diet, and their body weight reached an average of $58.25 \pm 0.19 \mathrm{~g}$. The study was conducted at the Faculty of Veterinary Medicine, Zagazig University, Egypt. The Ethics approved the experimental protocol of the Institutional Animal Care and Use Committee of Zagazig University, Egypt (ZUIACUC-2019). All animal experiments were performed following the recommendations described in "The Guide for the Care and Use of Laboratory Animals in scientific investigations". Chicks were housed within the same sanitary, environmental, and managerial conditions throughout the experimental period. The chicks were reared at $10 \mathrm{bird} / \mathrm{m}^{2}$ stocking density. The light regimen in all experimental pens was maintained at $23 \mathrm{~L}: 1 \mathrm{D} \mathrm{h}$ for the first 3 days, followed by $20 \mathrm{~L}: 4 \mathrm{D} \mathrm{h}$ until the end of the experiment. The initial ambient temperature was about $32{ }^{\circ} \mathrm{C}$ during the first week and then gradually reduced every week by $2{ }^{\circ} \mathrm{C}$ until it reached $22^{\circ} \mathrm{C}$; the relative humidity (RH\%) range was $65-75 \%$. Birds were reared in a naturally ventilated open house with sawdust as litter. General health and vaccination practices were followed against the New Castle (on 4th and 14th day) and Gumboro diseases (on 7 th and 22nd day). The health condition of all chicks was closely monitored. A daily check was performed on the chicks for any health challenges. After completion of the study, all remaining chickens were released.

\section{Experimental design and diets}

Vitamin C (ROVIMIX ${ }^{\circ}$ STAY-C $^{\circ} 35$ ) was primarily produced for use in the feed as a stable source of vitamin C. Safflower oil was extracted from safflower seeds by a screw press expeller according to the method described in [84].

Birds were randomly assigned to a $2 \times 3$ factorial design consisting of six experimental groups with five replicates (10 chicks/replicate). The experimental groups consisted of two vitamin C levels ( 0 and $400 \mathrm{mg} / \mathrm{kg}$ diet) and three levels of safflower oil $(0,5$, and $10 \mathrm{~g} / \mathrm{kg}$ diet $)$. The experiment lasted for 35 days and was allocated three periods: starter (from 4- ten days), grower (from 11 to 23 days), and finisher period (from 24 to 35 days). Freshwater and feed were offered for ad libitum consumption throughout the experiment. The proximate chemical composition of the experimental diets is shown in Table 8. Iso-energetic and iso-nitrogenous diets were formulated following Ross 308 broiler nutrition specifications, Aviagen [85].

\section{Growth performance}

The initial weight of the birds was obtained on the 4th day of age; the bodyweight "BW" was then recorded at the end of the starter, grower, and finisher stages (10, 23 , and 35 days, respectively) to estimate the average
BW of the birds in each group. The body weight gain "BWG" was calculated as W2-W1, where W2 is the final BW in the intended period, and W1 is the initial BW in the same period. Feed intake "FI" of each replicate was recorded as the difference between the weight of the feed offered and the residues left and then divided by the number of birds in each replicate to find out the average feed intake per bird. According to an earlier study, feed conversion ratio "FCR" was estimated at the end of each stage [86]. The relative growth rate (RGR) was calculated at the end of the experiment by the equation described in [87].

\section{Apparent ileal digestibility coefficient "AID\%" of amino acids}

Diet and birds

To determine the amino acid ileal digestibility, titanium dioxide was added to the feed at $0.5 \%$ dosage $(5 \mathrm{~kg} / \mathrm{t}$ of feed) for 5 days. It is an indigestible marker substance, characterized by a high recovery rate of almost $100 \%$, and does not affect the nutrients' digestibility. Each experimental diet was offered ad libitum to three replicates (five birds/replicate) of broiler chickens from 35 to 40 days of age. At the end of the digestibility trial, the birds were euthanized using cervical dislocation according to [88], and the contents of the lower half of the ileum were collected into plastic containers, pooled, frozen directly after collection, and then freeze-dried. Dried samples were ground and stored in airtight containers at $-20^{\circ} \mathrm{C}$ for chemical analysis.

\section{Analysis of amino acid concentration}

The concentration of amino acids in the diet and the ileal digesta samples were estimated by the method described in [89, 90]. Tryptophan was determined separately using the method of [91]. Titanium dioxide was estimated using the procedures of [92]. Amino acid AID\% was estimated by the following equation: AID $(\%)=100$ $\left[\left(\mathrm{Ti}_{(\text {diet) }} \times \mathrm{AA}_{\text {(ileum) })} /\left(\mathrm{TI}_{\text {(ileum) }} \times \mathrm{AA}_{(\text {diet) }}\right) \times 100\right]\right.$.

where $\mathrm{Ti}$ (diet) is the titanium dioxide concentration in the diet, Ti (ileal) is the titanium dioxide concentration in the ileal digesta, AA (ileal) is the concentration of the test AA in the ileal digesta, and AA (diet) is the concentration of the test $\mathrm{AA}$ in the diet.

\section{Histological examination of the gut}

The intestinal specimens of the broilers were collected and immediately fixed in $10 \%$ buffered neutral formalin solution for $48 \mathrm{~h}$, dehydrated in a gradual ascending concentration of ethanol (70, 80, 90, 95, and 100\%), cleared in xylene, and embedded in paraffin. Five-micron thick paraffin was sliced using a microtome (Leica RM 2155, England). The sections were prepared and then routinely stained with hematoxylin and eosin and examined 


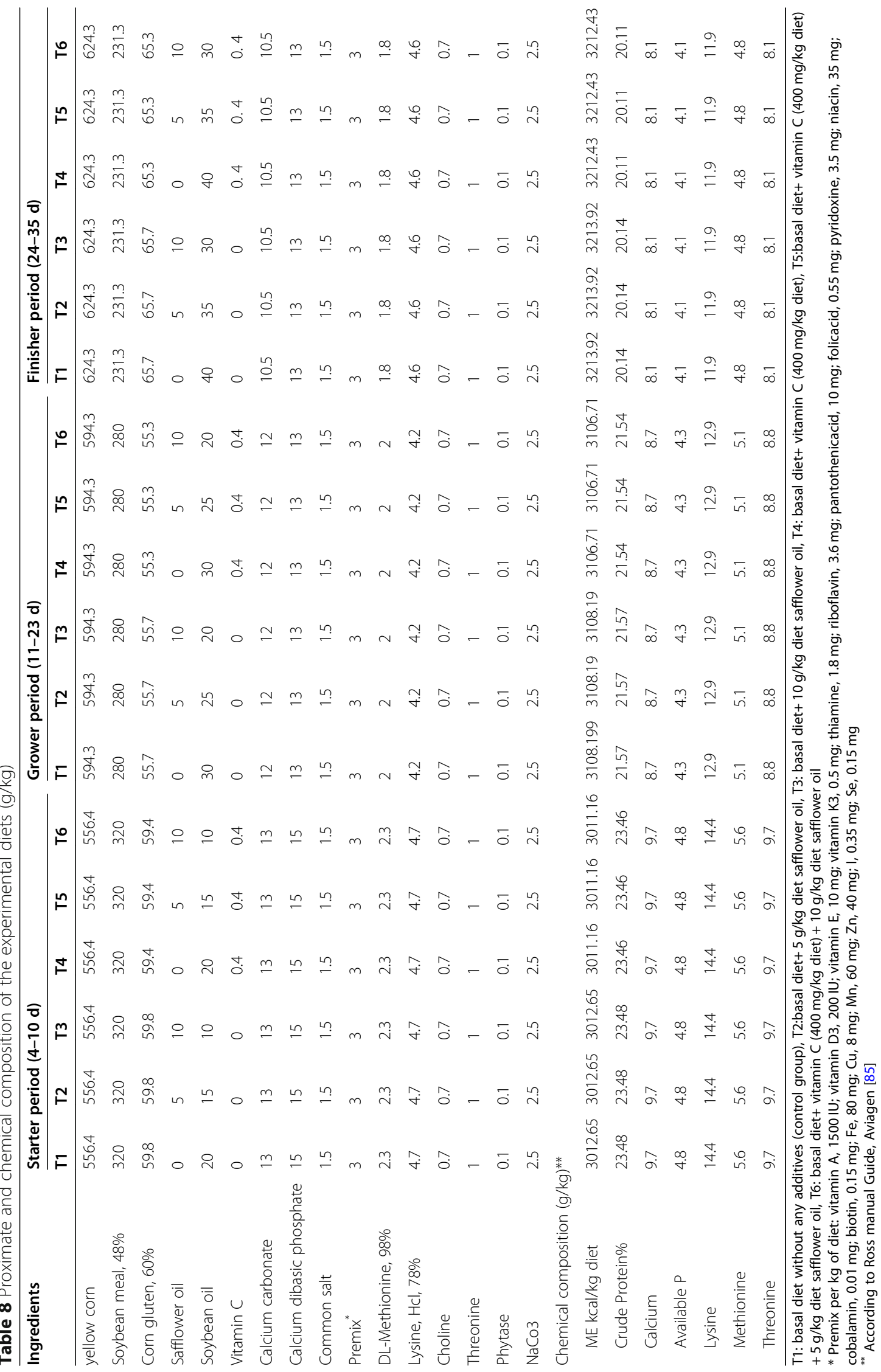


microscopically [93]. Morphometric analysis was performed by the camera microscope software AmScope ${ }^{\circ}$ (AmScope digital camera-attached Ceti England microscope) as follows: Villus height measured $(\mu \mathrm{m})$ from the tip to the base of the villus. The diameter, muscular thickness, submucosa layer thickness, the number of goblet cells per area of the epithelium layer, and intraepithelial leucocytes were also calculated.

\section{Carcass traits}

At the end of the trial period of 35 days, five birds from each group were selected, maintained under overnight fasting condition, weighed, and euthanized using cervical dislocation, according to [88]. The feathers were pulled out, and the birds were disassembled and weighed to determine the proportion of dressing. The dressed carcass, liver, gizzard, intestines, heart, spleen, bursa, and abdominal fat were calculated as a percentage of the live BW. The relative weight of some organs was calculated according to [94].

\section{Behavioral measurement}

The broilers' behavioral observation was recorded after fixing cameras over the experimental pens and recorded using a scan sampling technique [95]. Each group was observed twice daily (10 min each time), for six consecutive days per week (total $3 \mathrm{~h} /$ group/week) throughout the experimental period. The observation was carried out between 7 and 8 am and 2-3 pm.

The following behavioral parameters were observed and measured throughout the experiment: ingestive behavior (feeding, drinking), walking, standing, resting, comfort behavior (feather preening and other comforting activities that included wing flapping, head shaking, wing and leg stretches, and body shaking), foraging behavior, and feather pecking behavior as described in [96]. The number of birds performing each behavioral pattern was recorded in each scan $(10 \mathrm{~min})$, and the results were expressed as the percentage of birds performing the behavior/total number of observed birds [97].

\section{Sample collection}

At the end of the trial on day 35, birds were kept for fasting for $12 \mathrm{~h}$, and blood samples were withdrawn from five birds. These birds were selected randomly from each experimental group and were euthanized using cervical dislocation, according to [88]. Blood samples were allowed to coagulate at room temperature or in the refrigerator for $1 \mathrm{~h}$ and then centrifuged at $3000 \mathrm{rpm}$ for $15 \mathrm{~min}$. The clear supernatant serum was transferred into dry, sterile, and labeled stopper vials and used for the clinical and biochemical tests, including liver and kidney function, antioxidant defense system, and selective immunological parameters. Samples from different parts of the gut were dissected for histological examination of the gut. Breast muscles were stored in a refrigerator at $-20{ }^{\circ} \mathrm{C}$ until the estimation of malondialdehyde (MDA) level and fatty acid composition was performed.

\section{Determination of the fatty acid composition of breast muscle \\ Extraction of lipids}

Oils were extracted from the breast muscle using a solvent mixture of chloroform/methanol $(2: 1, \mathrm{v} / \mathrm{v})$, which is suitable for the quantitative extraction of lipids [98].

\section{Fatty acids separation and identification}

Fatty acids in the extracted oil were determined, as mentioned for the safflower oil method [99].

\section{Clinical and biochemical analyses}

Serum activities of AST and ALT were estimated by the method of Reitman and Frankel [100], urea and creatinine were evaluated according to Coulombe and Favreau [101, 102], respectively, using a semi-automated Photometer (5010 V5+, RIELE GmbH \& Co, Berlin, Germany) following the manufacturer's protocol.

Chicken ELISA kits from MyBioSource (CAT. NO. MBS012469) and ABCAM (CAT. NO. AB157691) were used to determine the serum levels of cortisone and IgA, respectively. Meanwhile, the sandwich ELISA (enzymelinked immunosorbent assay) kit from Life Span Biosciences, Inc. (CAT.NO.LS-F9287) was used for detecting the serum level of complement $\mathrm{C} 3$ following the instructions in the enclosed pamphlets.

Parameters of the antioxidant defense system, such as the serum level of CAT was estimated according to Aebi [103] and SOD, according to Nishikimi, et al. [104]. The serum level of reduced glutathione (GSH) was determined, according to an earlier study [105]. The Malondialdehyde (MDA) level was determined in the breast muscle according to Mcdonald and Hultin [106].

\section{Statistical analysis}

Experimental data were analyzed using SPSS 18.0 for Windows (SPSS Inc., Chicago, IL, USA). The variation was assessed by two-way ANOVA. A factorial analysis was conducted with the factors in the model being the levels of vitamin $C$, safflower oil, and their interactions. Differences between the means were compared at a $5 \%$ probability using the post-hoc Tukey's multiple comparison tests. Variation in the data was expressed as pooled SEM, and the significance level was set at $P<0.05$.

\section{Abbreviations}

AID\%: amino acid ileal digestibility coefficient; BW: body weight; BWG: body weight gain; Fl: feed intake; FCR: feed conversion ratio; RGR: relative growth rate; PER: protein efficiency ratio; Ti: Titanium dioxide; $A A$ : amino acid; HSP70: heat shock protein 70. 


\section{Acknowledgments}

Not applicable.

\section{Authors' contributions}

Design of the experiment: SAA and AEO. Methodology: SAA, WAMM, HSAG, NAA, AG, MTE, GIA, and AEO. Data collection: SAA, WAMM, HSAG, and AEO. Data analysis: SAA. Writing of the manuscript: SAA, AEO, and HSAG. All authors have read and approved the manuscript.

\section{Funding}

This research did not receive any specific grant from funding agencies in the public, commercial, or not-for-profit sectors.

\section{Availability of data and materials}

The datasets used and analyzed during the current study available from the corresponding author on reasonable request.

\section{Ethics approval and consent to participate}

The experimental protocol was approved by the Ethics of the Institutional Animal Care and Use Committee of Zagazig University, Egypt (ZUIACUC2019), and all animal experiments were performed following recommendations described in "The Guide for the Care and Use of Laboratory Animals in scientific investigations".

\section{Consent for publication}

Not applicable.

\section{Competing interests}

The authors declare that they have no conflict of interests.

\section{Author details}

'Department of Nutrition \& Clinical Nutrition, Faculty of Veterinary Medicine, Zagazig University, Zagazig 44511, Egypt. ${ }^{2}$ Department of Clinical Pathology, Faculty of Veterinary Medicine, Zagazig University, Zagazig 44511, Egypt. ${ }^{3}$ Department of Veterinary Public Health, Faculty of Veterinary Medicine, Zagazig University, Zagazig 44511, Egypt. ${ }^{4}$ Pathology Department, Faculty of Veterinary Medicine, Thamar University, Dahamar, Yemen. ${ }^{5}$ Department of Animal Production, National Research Centre, Dokki 12622, Egypt. ${ }^{6}$ College of Public Health and Molecular Diagnostics and Personalized Therapeutics Center (CMDPT) Hail University, Hail 2440, Saudi Arabia. ${ }^{7}$ Food Control Department, Faculty of Veterinary Medicine, Zagazig University, Zagazig 44519, Egypt.

Received: 4 April 2020 Accepted: 21 January 2021

Published online: 04 February 2021

\section{References}

1. Yau J-C, Denton J, Bailey C, Sams A. Customizing the fatty acid content of broiler tissues. Poul Sci. 1991;70(1):167-72.

2. Chanmugam P, Boudreau M, Boutte T, Park R, Hebert J, Berrio L, Hwang D. Incorporation of different types of n-3 fatty acids into tissue lipids of poultry. Poul Sci. 1992;71(3):516-21.

3. Kishawy AT, Amer SA, Abd El-Hack ME, Saadeldin IM, Swelum AA. The impact of dietary linseed oil and pomegranate peel extract on broiler growth, carcass traits, serum lipid profile, and meat fatty acid, phenol, and flavonoid contents. Asian-Australasian J Anim Sci. 2019;32(8):1161.

4. Olomu J, Baracos V. Influence of dietary flaxseed oil on the performance, muscle protein deposition, and fatty acid composition of broiler chicks. Poul Sci. 1991;70(6):1403-11.

5. Salmon R, Gardiner E, Klein K, Larmond E. Effect of canola (low glucosinolate) rapeseed meal, protein and nutrient density on performance, carcass grade, and canola meal on sensory quality of broilers. Poul Sci. 1981; 60:519-28.

6. Kinsella JE, Lokesh B, Stone RA. Dietary n-3 polyunsaturated fatty acids and amelioration of cardiovascular disease: possible mechanisms. Am J Clin Nutr. 1990;52(1):1-28.

7. Nettleton J. Omega-3 fatty acids: comparison of plant and seafood sources in human nutrition. J Am Diet Assoc. 1991:91(3):331-7.

8. Hargis PS, Van Elswyk ME. Manipulating the fatty acid composition of poultry meat and eggs for the health conscious consumer. Wor Poul Sci t. 1993;49(3):251-64.
9. Işigigür A, Karaosmanoglu F, Aksoy H. Characteristics of safflower seed oils of Turkish origin. J. of the Amer. Oil Chemists' Soci. 1995;72(10):1223-5.

10. Weiss E. Oilseed Crops. Tropical Series. In: Longman Inc. New York: Leonard Hill Books; 1983. p. 603.

11. Latha T, Prakash V. Studies on the proteins from safflower seed (Carthamus tinctorius L). J Agri Food Chem. 1984;32(6):1412-6.

12. Ashri A, Roebbelen G, Downey RK. Oil Crops of the World. New York: McGrawHill; 1989. p. 375-87.

13. Velasco L, Fernandez-Martinez J. Breeding for oil quality in safflower. In: Proceedings of the 5th international safflower conference: 2001; 2001. p. $133-7$

14. Kwon J-S, Snook JT, Wardlaw GM, Hwang DH. Effects of diets high in saturated fatty acids, canola oil, or safflower oil on platelet function, thromboxane B2 formation, and fatty acid composition of platelet phospholipids. Am J Clin Nutr. 1991;54(2):351-8.

15. Simon O, Männer K, Schäfer K, Sagredos A, Eder K. Effects of conjugated linoleic acids on protein to fat proportions, fatty acids, and plasma lipids in broilers. Euro J Lipid Sci Technol. 2000;102(6):402-10.

16. Szymczyk B, Pisulewski PM, Szczurek W, Hanczakowski P. Effects of conjugated linoleic acid on growth performance, feed conversion efficiency, and subsequent carcass quality in broiler chickens. Br J Nutr. 2001;85(4):465-73.

17. Pariza MW, Park Y, Cook ME. The biologically active isomers of conjugated linoleic acid. Prog Lipid Res. 2001;40(4):283-98.

18. Wahle KW, Heys SD, Rotondo D. Conjugated linoleic acids: are they beneficial or detrimental to health? Prog Lipid Res. 2004;43(6):553-87.

19. Bouthegourd J-C, Even PC, Gripois D, Tiffon B, Blouquit M-F, Roseau S, Lutton C, Tome D, Martin J-C. A CLA mixture prevents body triglyceride accumulation without affecting energy expenditure in Syrian hamsters. J Nutr. 2002;132(9):2682-9.

20. Degrace P, Demizieux L, Gresti J, Chardigny J-M, Sebedio J-L, Clouet P. Hepatic steatosis is not due to impaired fatty acid oxidation capacities in C57BL/6J mice fed the conjugated trans-10, cis-12-isomer of linoleic acid. J Nutr. 2004;134(4):861-7.

21. Park Y, Albright KJ, Liu W, Storkson JM, Cook ME, Pariza MW. Effect of conjugated linoleic acid on body composition in mice. Lipids. 1997;32(8): 853-8.

22. Lin C, Gray J, Asghar A, Buckley D, Booren A, Flegal C. Effects of dietary oils and a-tocopherol supplementation on lipid composition and stability of broiler meat. J Food Sci. 1989;54(6):1457-60.

23. Engberg RM, Lauridsen C, Jensen SK, Jakobsen K. Inclusion of oxidized vegetable oil in broiler diets. Its influence on nutrient balance and on the antioxidative status of broilers. Poul Sci. 1996;75(8):1003-11.

24. Vercellotti JR, St. Angelo AJ, Spanier AM. Lipid Oxidation in Foods. In: Lipid Oxidation in Food. Volume 500, edn. American Chemical Society; 1992:1-11.

25. Khan R. Antioxidants and poultry semen quality. Wor Poul Sci J. 2011;67(2): 297-308.

26. Ghazi S, Amjadian T, Norouzi S. Single and combined effects of vitamin $C$ and oregano essential oil in diet, on growth performance, and blood parameters of broiler chicks reared under heat stress condition. Intern J Biomet. 2015;59(8):1019-24.

27. Attia YA, Al-Harthi MA, El-Shafey AS, Rehab YA, Kim WK. Enhancing tolerance of broiler chickens to heat stress by supplementation with vitamin E, vitamin C and/or probiotics. Ann Anim Sci. 2017;17(4):1155-69.

28. Hajati H, Hassanabadi A, Golian A, Nassiri-Moghaddam H, Nassiri MR. The effect of grape seed extract and vitamin C feed supplementation on some blood parameters and HSP70 gene expression of broiler chickens suffering from chronic heat stress. Ital J Anim Sci. 2015;14(3):3273.

29. Packer JE, Slater T, Willson R. Direct observation of a free radical interaction between vitamin E and vitamin C. Nature. 1979;278(5706):737.

30. King A, Uijttenboogaart T, De Vries A. a-Tocopherol, $\beta$-carotene and ascorbic acid as antioxidants in stored poultry muscle. J Food Sci. 1995; 60(5):1009-12.

31. Gouda A, Amer SA, Gabr S, Tolba SA. Effect of dietary supplemental ascorbic acid and folic acid on the growth performance, redox status, and immune status of broiler chickens under heat stress. Trop Anim Health Prod. 2020;52: 2987-96.

32. Halliwell B, Gutteridge JM. Free radicals in biology and medicine. USA: Oxford University Press; 2015

33. Fred Gey K. Vitamins $E$ plus $C$ and interacting conutrients required for optimal health. BioFactors. 1998;7(1-2):113-74. 
34. Caspary WF. Physiology and pathophysiology of intestinal absorption. Am J Clin Nutr. 1992;55(1):2995-308S.

35. Xu Z, Hu C, Xia M, Zhan X, Wang M. Effects of dietary fructooligosaccharide on digestive enzyme activities, intestinal microflora and morphology of male broilers. Poul Sci. 2003;82(6):1030-6.

36. Onderci M, Sahin N, Sahin K, Cikim G, Aydin A, Ozercan I, Aydin S. Efficacy of supplementation of a-amylase-producing bacterial culture on the performance, nutrient use, and gut morphology of broiler chickens fed a corn-based diet. Poul Sci. 2006;85(3):505-10.

37. Amer SA, Naser MA, Abdel-Wareth AA, Saleh AA, Elsayed SA, Abdel Fattah DM, Metwally AE. Effect of dietary supplementation of alpha-galactosidase on the growth performance, ileal digestibility, intestinal morphology, and biochemical parameters in broiler chickens. BMC Vet Res. 2020;16:1-13.

38. Omar AE, Al-Khalaifah HS, Mohamed WA, Gharib HS, Osman A, Al-Gabri NA, Amer SA. Effects of Phenolic-Rich Onion (Allium cepa L.) Extract on the Growth Performance, Behavior, Intestinal Histology, Amino Acid Digestibility, Antioxidant Activity, and the Immune Status of Broiler Chickens. Frontiers Vet Sci. 2020;7:728.

39. Nain S, Renema R, Zuidhof M, Korver D. Effect of metabolic efficiency and intestinal morphology on variability in $n-3$ polyunsaturated fatty acid enrichment of eggs. Poul Sci. 2012;91(4):888-98.

40. Cowieson A, Zaefarian F, Knap I, Ravindran V. Interactive effects of dietary protein concentration, a mono-component exogenous protease and ascorbic acid on broiler performance, nutritional status and gut health. Anim Prod Sci. 2017:57(6):1058-68.

41. Ibrahim RE, Ahmed SA, Amer SA, Al-Gabri NA, Ahmed Al, Abdel-Warith AWA, Younis E-SM, Metwally AE. Influence of vitamin C feed supplementation on the growth, antioxidant activity, immune status, tissue histomorphology, and disease resistance in Nile tilapia, Oreochromis niloticus. Aqua Rep. 2020; 18:100545.

42. Alao S, Balnave D. Nutritional significance of different fat sources for growing broilers. Poul Sci. 1985;64(8):1602-4.

43. Su W, Jones PJ. Dietary fatty acid composition influences energy accretion in rats. J Nutr. 1993;123(12):2109-14.

44. Zollitsch W, Knaus W, Aichinger F, Lettner F. Effects of different dietary fat sources on performance and carcass characteristics of broilers. Anim Feed Sci Technol. 1997;66(1-4):63-73.

45. Pinchasov $Y$, Nir I. Effect of dietary polyunsaturated fatty acid concentration on performance, fat deposition, and carcass fatty acid composition in broiler chickens. Poul Sci. 1992;71(9):1504-12.

46. Metwally AE, Abdel-Wareth AA, Saleh AA, Amer SA. Are the energy matrix values of the different feed additives in broiler chicken diets could be summed? BMC Vet Res. 2020;16(1):1-11.

47. Shimomura $Y$, Tamura T, Suzuki M. Less body fat accumulation in rats fed a safflower oil diet than in rats fed a beef tallow diet. J Nutr. 1990;120(11): 1291-6.

48. Korver D, Roura E, Klasing K. Effect of dietary energy level and oil source on broiler performance and response to an inflammatory challenge. Poul Sci. 1998;77(8):1217-27.

49. Kutlu H, Forbes J. Changes in growth and blood parameters in heatstressed broiler chicks in response to dietary ascorbic acid. Livestock Prod Sci. 1993;36(4):335-50.

50. Njoku P. Effect of dietary ascorbic acid (vitamin C) supplementation on the performance of broiler chickens in a tropical environment. Anim Feed Sci Technol. 1986:16(1-2):17-24.

51. Pardue S, Thaxton JP, Brake J. Influence of supplemental ascorbic acid on broiler performance following exposure to high environmental temperature. Poul Sci. 1985;64(7):1334-8.

52. Abdul QR, Aijazuddin Q. Effectiveness of supplementation of vitamin C in broiler feeds in hot season. Pak Vet J. 2000;20(2):100

53. Sahin K, Kucuk O. Effects of vitamin C and vitamin E on performance, digestion of nutrients and carcass characteristics of Japanese quails reared under chronic heat stress (34 C). J Anim Physiol Anim Nutr. 2001;85(11-12): $335-41$

54. Kucuk O, Sahin N, Sahin K. Supplemental zinc and vitamin a can alleviate negative effects of heat stress in broiler chickens. Biol Trace Elem Res. 2003; 94(3):225-35.

55. Hallberg $L$, Brune $M$, Rossander $L$ : The role of vitamin $C$ in iron absorption. International journal for vitamin and nutrition research Supplement= Internationale Zeitschrift fur Vitamin-und Ernahrungsforschung Supplement 1989, 30:103-108.
56. Amer SA, Kishawy AT, Osman A, Mahrose KM, Hassanine E-SI, Rehman ZU. Influence of dietary graded levels of lycopene on the growth performance, muscle cholesterol level and oxidative status of Japanese quail fed high-fat diet. An Acad Bras Cienc. 2020;92:(Suppl. 2).

57. Ciftci M, Ertas ON, Guler T. Effects of vitamin E and vitamin C dietary supplementation on egg production and egg quality of laying hens exposed to a chronic heat stress. Revue Med Vet. 2005;156(2):107-11.

58. McKee J, Harrison P. Effects of supplemental ascorbic acid on the performance of broiler chickens exposed to multiple concurrent stressors. Poul Sci. 1995;74(11):1772-85.

59. Khan R, Naz S, Nikousefat Z, Selvaggi M, Laudadio V, Tufarelli V. Effect of ascorbic acid in heat-stressed poultry. Wor Poul Sci J. 2012;68(3):477-90.

60. Chand N, Naz S, Khan A, Khan S, Khan RU. Performance traits and immune response of broiler chicks treated with zinc and ascorbic acid supplementation during cyclic heat stress. Intern J Biomet. 2014;58(10): 2153-7.

61. El Iraqi K, Abdelgawad E, Ibrahim H, El Sawe AE. Effect of Gingko Biloba, dry peppermint and vitamin $\mathrm{C}$ as anti-stress on broiler welfare during summer heat stress. Glob Vet. 2013;10(7):770-8.

62. Nosrati M, Javandel F, Camacho L, Khusro A, Cipriano M, Seidavi A, Salem A. The effects of antibiotic, probiotic, organic acid, vitamin C, and Echinacea purpurea extract on performance, carcass characteristics, blood chemistry, microbiota, and immunity of broiler chickens. J Appl Poul Res. 2017;26(2): 295-306.

63. Raza T, Chand N, Khan RU, Shahid MS, Abudabos AM. Improving the fatty acid profile in egg yolk through the use of hempseed (Cannabis sativa), ginger (Zingiber officinale), and turmeric (Curcuma longa) in the diet of $\mathrm{Hy}$ line white leghorns. Arch Anim Breed. 2016;59(2):183.

64. Leclercq B. Leanness in Domestic Birds. In: Leclercq B, Whitehead CC, editors. Institut National de la Recherche Agronomique. London: Butterworths; 1988.

65. Kirchgessner M, Ristic M, Kreuzer M, Roth F. Inclusion of fats with high quantities of free fatty acids in broiler diets, 2: growth as well as quality of carcass, meat and fat as affected by the stepwise substitution of saturated by unsaturatedfatty acids. Arch fuer Gefluegelkunde (Germany). 1993;57: 265-274.

66. Stahly TS. Fats in animal nutrition, ed. J. Wiseman. London: Butterworths; 1984. p. 313-31.

67. Enser M. chemistry, biochemistry and nutritional importance of animal fats. Proceedings-Easter School in Agricultural Science, University of Nottingham. Fats in Anim Nutr. 1984;23-51.

68. Keller HR, Dreyer C, Medin J, Mahfoudi A, Ozato K, Wahli W. Fatty acids and retinoids control lipid metabolism through activation of peroxisome proliferator-activated receptor-retinoid $X$ receptor heterodimers. Proceed Nat Acad Sci. 1993:90(6):2160-4.

69. Rise P, Galli C. Arachidonic and docosahexaenoic acids differentially affect the expression of fatty acyl-CoA oxidase, protein kinase $C$ and lipid peroxidation in HepG2 cells. Prostaglandins Leukot Essent Fat Acids. 1999; 60(5-6):367-70.

70. Emmans G. Effective energy: a concept of energy utilization applied across species. Br J Nutr. 1994;71(6):801-21.

71. Laudicina DC, Marnett $L$. Enhancement of hydroperoxide-dependent lipid peroxidation in rat liver microsomes by ascorbic acid. Arch Bioch Biophys. 1990;278(1):73-80

72. Sahin K, Sahin N, Yaralioglu S. Effects of vitamin C and vitamin E on lipid peroxidation, blood serum metabolites, and mineral concentrations of laying hens reared at high ambient temperature. Biol Trace Elem Res. 2002; 85(1):35-45.

73. Öztürk-Ürek R, Bozkaya LA, Tarhan L. The effects of some antioxidant vitaminand trace element-supplemented diets on activities of SOD, CAT, GSH-Px and LPO levels in chicken tissues. Cell Biochem Function. 2001;19(2):125-32.

74. Florou-Paneri P, Giannenas I, Christaki E, Govaris A, Botsoglou N. Performance of chickens and oxidative stability of the produced meat as affected by feed supplementation with oregano, vitamin C, vitamin E and their combinations. Arch fur Geflugelkunde. 2006;70(5):232-9.

75. Bendich A. Antioxidant vitamins and their functions in immune responses, In: Antioxidant nutrients and immune functions. vol. 262. edn.: Springer; 1990. p. 35-55.

76. Wu C, Dorairajan T, Lin T. Effect of ascorbic acid supplementation on the immune response of chickens vaccinated and challenged with infectious bursal disease virus. Vet Immun Immunopath. 2000;74(1-2):145-52. 
77. Asli MM, Hosseini SA, Lotfollahian H, Shariatmadari F. Effect of probiotics, yeast, vitamin $\mathrm{E}$ and vitamin $\mathrm{C}$ supplements on performance and immune response of laying hen during high environmental temperature. Intern J Poult Sci. 2007:6(12):895-900.

78. Pardue SL, Thaxton JP, Brake J. Role of ascorbic acid in chicks exposed to high environmental temperature. J Appl Physiol. 1985;58(5):1511-6.

79. Dieter MP, Breitenbach RP. Vitamin C in lymphoid organs of rats and cockerels treated with corticosterone or testosterone. Proceed Soci Exper Biol Med. 1971;137(1):341-6.

80. Sijben J, Nieuwland M, Kemp B, Parmentier H, Schrama J. Interactions and antigen dependence of dietary n-3 and n-6 polyunsaturated fatty acids on antibody responsiveness in growing layer hens. Poul Sci. 2001;80(7):885-93.

81. Calder PC. Immunomodulatory and anti-inflammatory effects of n-3 polyunsaturated fatty acids. Proceed Nutr Soci. 1996;55(2):737-74.

82. Selvaraj RK, Cherian G. Changes in delayed type hypersensitivity, egg antibody content and immune cell fatty acid composition of layer birds fed conjugated linoleic acid, n-6 or n-3 fatty acids. Can J Anim Sci. 2004;84(2): 221-8.

83. Erdoğan Z, Erdoğan S, Aksu T, Baytok E. The effects of dietary lead exposure and ascorbic acid on performance, lipid peroxidation status and biochemical parameters of broilers. Turk J Vet Anim Sci. 2005;29(4):1053-9.

84. Knowles P. Processing seeds for oil in towns and villages of Turkey, India and Egypt. Eco Bot. 1967;21(2):156-62.

85. Aviagen R. Ross Broiler Management Manual. 2009. Available online: http:// goldenpoultry.com/wp-content/uploads/2014/09/Ross-Broiler-Handbook-2 014i-EN.pdf. Accessed 6 Nov 2014.

86. Wanger D, Furrow R, Bradly B. Sub chronic toxicity of growth promoters in broiler chickens. Vet Path. 1983;20:253-359.

87. Brody S. Bioenergetics and growth: with special reference to the efficiency complex in domestic animals. Bioenergetics and growth: with special reference to the efficiency complex in domestic animals. New York, London: Hafner, Collier Macmillan; 1964.

88. Association AVM: AVMA guidelines for the euthanasia of animals: 2013 American Veterinary Medical Association, Schaumburg 2013.

89. Siriwan P, Bryden W, Mollah Y, Annison E. Measurement of endogenous amino acid losses in poultry. Br Poul Sci. 1993;34(5):939-49.

90. Li X, Ni Gusti Ayu M, Zhang D, Bryden W: Apparent ileal amino acid digestibility of Australian sorghum. 2006. 18th annual Australian poultry science symposium, Sydney: The Poul Res Found.

91. Ravindran G, Bryden W. Tryptophan determination in proteins and feedstuffs by ion exchange chromatography. Food Chem. 2005;89(2): 309-14.

92. Fenton T, Fenton M. An improved procedure for the determination of chromic oxide in feed and feces. Can J Anim Sci. 1979;59(3):631-4.

93. Suvarna S, Layton C, Bancroft J. The hematoxylins and eosin. Bancroft's Theory and Practice of Histological Techniques. 7th ed. London: Churchill Livingstone; 2013. p. 172-86.

94. El-Samee A: The effect of feeding and environmental temperature on duck performance. Ph. D. Thesis Faculty of Agriculture, Animal production department, Cairo 1995.

95. Armitage K, Salsbury C, Barthelmess E, Gray R, Kovach A: ALTMANN, J. 1974. Observational study of behavior: sampling methods. Behaviour 49: 227-267. ARMITAGE, KB 1981. Sociality as a life-history tactic of ground squirrels. Oecologia 48: 36-49. ARMITAGE, KB 1999. Evolution of sociality in marmots. Journal of Mammalogy 80: 1. The socioecology, mating system and behavior of round-tailed ground squirrels (Xerospermophilus tereticaudus) 2011, 74:54.

96. Mahmoud UT, Abdel-Rahman MAM, Darwish MHA, Applegate TJ. Cheng HW: behavioral changes and feathering score in heat stressed broiler chickens fed diets containing different levels of propolis. Appl Anim Behav Sci. 2015; 166:98-105.

97. Mohammed HH, Badawi M, Walaa M, Ali M, Abd El-Aziz R. The influence of chromium sources on growth performance, economic efficiency, some maintenance behaviour, blood metabolites and carcass traits in broiler chickens. Glob Vet. 2014;12(5):599-605.

98. Belitz H-D, Grosch W, Schieberle P. Meat. Food Chem. 4th revised and extended ed. 2009:563-616.

99. AOAC: Official methods of analysis of AOAC international; 2000.

100. Reitman S, Frankel S. Determination of serum glutamic oxaloacetic transaminase and pyruvic transaminase by colorimetric method. Am J Clin Path. 1957;28:57-65.
101. Coulombe J, Favreau L. A new simple semimicro method for colorimetric determination of urea. Clin Chem. 1963;9(1):102-8.

102. Larsen K. Creatinine assay in the presence of protein with LKB 8600 Reaction Rate Analyser. Clin Chim Acta. 1972;38(2):475.

103. Aebi $\mathrm{H}$ : Catalase in vitro. In: Methods in enzymology. Volume 105, edn:: Elsevier; 1984: 121-126.

104. Nishikimi M, Rao NA, Yagi K. The occurrence of superoxide anion in the reaction of reduced phenazine methosulfate and molecular oxygen. Biochem Biophys Res Comm. 1972;46(2):849-54.

105. Beutler E. Improved method for the determination of blood glutathione. J Lab Clin Med. 1963;61:882-8.

106. Mcdonald RE, Hultin HO. Some characteristics of the enzymic lipid peroxidation system in the microsomal fraction of flounder skeletal muscle. J Food Sci. 1987;52(1):15-21.

\section{Publisher's Note}

Springer Nature remains neutral with regard to jurisdictional claims in published maps and institutional affiliations.
Ready to submit your research? Choose BMC and benefit from:

- fast, convenient online submission

- thorough peer review by experienced researchers in your field

- rapid publication on acceptance

- support for research data, including large and complex data types

- gold Open Access which fosters wider collaboration and increased citations

- maximum visibility for your research: over $100 \mathrm{M}$ website views per year

At BMC, research is always in progress.

Learn more biomedcentral.com/submissions 